Article

\title{
High Cell Density Cultivation of Saccharomyces cerevisiae with Intensive Multiple Sequential Batches Together with a Novel Technique of Fed-Batch at Cell Level (FBC)
}

\author{
Kwanruthai Malairuang 1,2,3®D, Morakot Krajang ${ }^{1}$, Jatuporn Sukna ${ }^{1,2,3}$, \\ Krongchan Rattanapradit ${ }^{3,4, *}$ and Saethawat Chamsart 1,2,3,*(D) \\ 1 Biological Science Program, Faculty of Science, Burapha University, Chon Buri 20131, Thailand; \\ pinsor_17@hotmail.com (K.M.); morakoto_2@hotmail.com (M.K.); jatuporn08@gmail.com (J.S.) \\ 2 Department of Biology, Faculty of Science, Burapha University, Chon Buri 20131, Thailand \\ 3 Biochemical Engineering Pilot Plant, Faculty of Science, Burapha University, Chon Buri 20131, Thailand \\ 4 Department of Biotechnology, Faculty of Science, Burapha University, Chon Buri 20131, Thailand \\ * Correspondence: krongchan@buu.ac.th (K.R.); saethawa@buu.ac.th (S.C.); \\ Tel.: +6663-941-5993 (K.R.); +6696-887-3878 (S.C.)
}

Received: 28 August 2020; Accepted: 14 October 2020; Published: 21 October 2020

\begin{abstract}
High cell density cultivation (HCDC) is developed for the production of microbial biomasses and their products. They must be produced from high concentrations of substrate, e.g., glucose or sucrose. In batch culture, a high concentration of those sugars $>40-50 \%(w / v)$ cannot efficiently be utilized because of a dissolved $\mathrm{O}_{2}$ limitation causing the Crabtree effect that produces toxic by-products, i.e., ethanol and/or acetate, that inhibit cell growth. To prevent this effect, the HCDC is conducted with the fed-batch strategies. However, it has many disadvantages, i.e., complicated operations. To overcome those problems, this study was designed to use a new, efficient C-source (carbon source) substrate, namely dextrin, an oligomer of glucose. It can be utilized by yeast at a very high concentration of $\sim 100 \mathrm{~g} / \mathrm{L}$ although using just batch cultivation. As it is gradually hydrolyzed to release glucose molecules and gradually assimilated into the cells as "fed-batch at the cell level" (FBC), it prevents the yeast cell system from undergoing the Crabtree effect. In this research, the types of medium, the types of sugar compared with dextrin, and the concentrations of yeast extract (YE) were studied. The batch production medium (BPM) with dextrin and YE performed very good results. The concentrations of dextrin for yeast cultivation were studied in the aerobic batch 5-L bioreactors. Its optimum concentration was at $90 \mathrm{~g} / \mathrm{L}$ with $9 \mathrm{~g} / \mathrm{L}$ of $\mathrm{YE}$ in $3 \times \mathrm{BPM}$. It was operated at $3 \mathrm{~W} / \mathrm{kg}$ energy dissipation rate per unit mass $\left(\bar{\varepsilon}_{T}\right)$ and $3 \mathrm{vvm}$ airflow rate. Further, the intensive multiple sequential batch (IMSB) technique of high intensities of agitation speed and airflow was developed to achieve higher yield and productivity. The maximum values of cell biomass, specific growth rate, yield coefficient, productivity, and efficiency were at $55.17 \mathrm{~g} / \mathrm{L}, 0.21 \mathrm{~h}^{-1}, 0.54 \mathrm{~g} / \mathrm{g}, 2.30 \mathrm{~g} / \mathrm{L} / \mathrm{h}$, and $98.18 \%$, respectively. The studies of cell growth kinetics, biochemical engineering mass balances, and fluid dynamics for the design of impeller speeds of the 5-L bioreactors during the cultivations of yeast using dextrin at the high concentrations were successful. The results can be used for the scale-up of bioreactor for the industrial production of yeast cell biomass at high concentrations.
\end{abstract}

Keywords: high cell density cultivation (HCDC); intensive multiple sequential batch (IMSB); cell cultivation; fed-batch at cell level (FBC); S. cerevisiae; dextrin; bioreactor 


\section{Introduction}

Since the end of the 19th century to 2020, the addition of exogenous yeast biomass to produce bread, beer, wine, and industrial ethanol has become a common practice. Wineries started using exogenous yeast inoculants in the 1950s. In the 1960s, yeast biomass-producing plants contributed to the technology of producing large amounts of active dry yeast (ADY) or yeast cell biomass, and its use rapidly spread to European, North America, Asian, and other countries. Nowadays, modern industries require very large amounts of selected yeasts to obtain high-quality reproducible products and to ensure fast, complete cultivations. Efficient and profitable factory-scale processes have been developed to produce yeast biomass. The standard process was empirically optimized to obtain the highest yield by increasing biomass and decreasing production costs [1]. The ADY or yeast cell biomass is a yeast product that is dehydrated and dried from the fresh yeast. The dry yeast products are mainly used in the bakery, brewery, winery, feeds, pharmaceuticals, and ethanol industries, etc. The global production of ADY increased from 589.70 MT (metric tons) in 2010 to 862.50 MT in 2014, with an annual average growth rate of $7.91 \%$ [2]. It is estimated to a value of 1544.74 MT in 2024.

Saccharomyces cerevisiae is the most prominent in the yeast group. S. cerevisiae is a species of the budding yeasts in a group of unicellular fungi. It is a free-living organism with rapid growth and is simple for cultivation under a defined condition. As profound knowledge of its genetics, functional genomics, biochemistry, physiology, etc. of this yeast is presently available, it is widely used as a model eukaryote for certain studies [3], e.g., fermentation, aerobic cell cultivation, and molecular biology. It is a particularly suitable organism for biological studies and is generally regarded as safe status (GRAS). Moreover, it can produce a wide range of biological products of both wild types, e.g., single cell proteins and $\beta$-glucans [4], and recombinant products, e.g., viral vaccines and certain proteins [5]. More than 47 natural bioproducts have been produced in yeasts [6]. For those reasons, it was used herein as the model yeast for this study.

High cell density cultivation (HCDC) is a potential technique that has been developed to produce microbial cell biomasses at high concentrations and subsequently to gain relatively high product concentrations. It is used in various bioprocesses to achieve the cost-effective production of desired products. HCDC can be applied to produce a variety of biological products from microbial cells, such as cell biomasses, probiotics, single cell proteins, amino acids, organic acids, bioplastics, biochemicals, pharmaceuticals, etc. HCDC is a relative term with no exact concentration of dry cell weight value. In general, a cell concentration of more than those achieved in conventional cultivation has been considered as the high cell density. Most experiments have dry cell weights ranging from 20 to $40 \mathrm{~g} / \mathrm{L}$, and if they are higher than $100 \mathrm{~g} / \mathrm{L}$ they are designated as having a high cell density concentration (modified from [7]). They are normally operated with the fed-batch mode. There has not been any batch cultivation to achieve a high cell concentration at a high productivity by using high concentration of dextrin or oligomer as a carbon source (C-source), but we have successfully done this. This is unlike an anaerobic SSF (simultaneous saccharification and fermentation), a fermentation method using maltodextrin as a substrate at high titer without the problem of oxygen requirement. The HCDC is principally designed as the fed-batch mode to control the carbon substrate feeding in order to avoid cell growth inhibition due to too high a concentration of substrate and the accumulation of toxic by-products. The substrate feeding strategies are implemented to eliminate the problems of using high concentrations of substrates, especially glucose and sucrose, that effect to the biosynthesis of growth inhibitory by-products due to the Crabtree effect [8]. The fed-batch HCDC development often studies the optimum conditions of two main factors, i.e., medium feeding and cultivation strategies.

A defined medium is generally used to obtain a high cell density concentration because the nutrient amounts are known and can be controlled during cultivation while complex medium can vary in composition and quality making fermentation less reproducible. However, semi-defined or complex media are sometimes necessary to boost cell growth and product formation. The use of a defined medium with a single or a few amino acids to achieve high cell biomass and/or recombinant proteins would be attractive [9]. Although the fed-batch method is complicated, the results of some 
research works using fed-batch cultivations to produce yeast cell biomass have been reported. The dry cell weights and productivities of $187.63 \mathrm{~g} / \mathrm{L}$ and $1.71 \mathrm{~g} / \mathrm{L} / \mathrm{h}$ were obtained from [10], $120 \mathrm{~g} / \mathrm{L}$ and $1.84 \mathrm{~g} / \mathrm{L} / \mathrm{h}$ [11], $95.7 \mathrm{~g} / \mathrm{L}$ and $1.20 \mathrm{~g} / \mathrm{L} / \mathrm{h}$ [12], and 63.30-96.10 g/L and 1.33-1.99 g/L/h [13].

For aerobic cultivation, using sugar as a substrate at a high concentration usually causes the Crabtree effect. Although glycerol is generally used to minimize this effect, it can be utilized by microorganisms at a limited concentration, though its advantage generates a higher degree of reduction per carbon atom when compared to other sugars [14]. As a result, in this study, dextrin, an oligomer of glucose from cassava starch liquefaction was used as the major C-source substrate. It can efficiently be used at a high concentration. So far, there have not been any other research reports using dextrin or other oligomers as the potential C-source to prevent the system from oxygen limitation, especially for the aerobic batch cultivation operation to achieve a high cell density. Our new finding herein essentially explains that the dextrin oligomer regulates gradual glucose assimilation into the yeast cells, as so-called the "fed-batch at cell level" (FBC). It also plays a key role in a reserved C-source in the cultivation system when it is in the mixture of glucose.

Both fed-batch and continuous techniques usually: (i) require more types and units of equipment and (ii) complicated process steps; (iii) entail a high cost of operation, (iv) long time cultivation and time-consuming both in up-stream and down-stream processes, and (v) induce the Crabtree effect problem to inhibit cell growth because of using glucose and sucrose at high concentrations. Here, in order to achieve a high cell density concentration at a high production rate, these problems can be overcome by: (i) the use of aerobic batch mode with (ii) the use of a simple-defined minimal medium, (iii) the ability to use high concentrations of $C$-source substrate, (iv) the cultivation with a short time course, (v) with the intensive multiple sequential batches, (vi) the use of dextrin, oligomer of glucose from cassava starch liquefaction as the major substrate; (vii) the control of "fed-batch at cell level", and (viii) the prevention of the yeast cultivation system from the Crabtree effect to achieve these system balances, operating at the high intensities of (ix) aeration rates and (x) impeller agitation speeds, both proportional to the high concentrations of the C-source dextrin and the BPM (batch production medium).

These are the objectives of this research work in order to achieve high cell density cultivation of the model yeast at a high productivity with comprehensive and profound explanations of the details of all aspects, from culture medium design, new cultivation technique, kinetics of cell growth, and biochemical engineering mass balance models of substrate utilizations to regulate the fed-batch at cell level (FBC), through fluid dynamics, and reactor scale-up for the industries.

This study isolates the problem of the efficient operation of $S$. cerevisiae cultivation in bioreactors focusing only on the need for high cell density cultures. On this basis, the novelty of the FBC technique is proposed. It has been explained in principles and details of the cultivation technique, the potential substrate dextrin, the mechanism of substrate utilization to regulate the FBC, the FBC kinetics, and material balances, through the bioreactor design and scale-up.

\section{Materials and Methods}

\subsection{Yeast Strain and Preparations of Inoculants and Culture Media}

The stock of Saccharomyces cerevisiae S3, a strain of model yeasts was from the Microbiology Department, Faculty of Science, Burapha University, Thailand. It was maintained in YPD (Yeast Peptone Dextrose) medium, (composed of $10 \mathrm{~g} / \mathrm{L}$ of yeast extract, $10 \mathrm{~g} / \mathrm{L}$ of peptone, and $20 \mathrm{~g} / \mathrm{L}$ of dextrose) at $\mathrm{pH} 4.5$, then mixed with a cryo-protective agent of glycerol at $15 \%(v / v)$ and stored in 2-mL cryo-tubes at $-40{ }^{\circ} \mathrm{C}$ as the stocks. Before use, they were activated by defrosting at a room temperature of $28-30^{\circ} \mathrm{C}$ and then transferred into the 10-mL YPD contained in the 50-mL Erlenmeyer flasks. The cultures were incubated at $30^{\circ} \mathrm{C}$ in a rotary incubator shaker at a speed of $200 \mathrm{rpm}$ overnight. Then, 5-mL volumes were transferred into the 20-mL YPD contained in the 50-mL baffled flasks and cultured at the same conditions (i.e., $\mathrm{pH}$, temperature, and shaker speed above) for $18 \mathrm{~h}$. Further, 
10-mL volumes were transferred into the 100-mL YPD contained in the 500-mL baffled flasks and again cultured at the same conditions for $18 \mathrm{~h}$ to use as the inoculants for further cultivation experiments in the 5-L fermenters of Topic 2.6. They had an optical density $\left(\mathrm{OD}_{600 \mathrm{~nm}}\right)$ of about 8-10. To increase the inoculum concentration at an $\mathrm{OD}_{600 \mathrm{~nm}}$ of $\sim 15-18$, the cultures were grown for $24 \mathrm{~h}$. This was used for the initial batch of the intensive multiple sequential batch cultivation in Topic 2.7.

The batch production medium (BPM) [15], the minimal synthetic defined medium containing $\left(\mathrm{L}^{-1}\right)$ of $2.2 \mathrm{~g}\left(\mathrm{NH}_{4}\right)_{2} \mathrm{SO}_{4}, 1.5 \mathrm{~g} \mathrm{KH}_{2} \mathrm{PO}_{4}, 1.8 \mathrm{~g} \mathrm{Na}_{2} \mathrm{HPO}_{4}, 0.2 \mathrm{~g} \mathrm{MgSO}_{4} .7 \mathrm{H}_{2} \mathrm{O}$, and $1.0 \mathrm{~mL}$ of trace element solution, was composed of $\left(\mathrm{L}^{-1}\right)$ of $10.0 \mathrm{~g} \mathrm{CaCl}_{2} \cdot 2 \mathrm{H}_{2} \mathrm{O}, 6.0 \mathrm{~g}\left(\mathrm{NH}_{4}\right)_{5}\left[\mathrm{Fe}\left(\mathrm{C}_{6} \mathrm{H}_{4} \mathrm{O}_{7}\right)_{2}\right], 0.2 \mathrm{~g} \mathrm{CoCl} 2.6 \mathrm{H}_{2} \mathrm{O}$, $0.3 \mathrm{~g} \mathrm{H}_{3} \mathrm{BO}_{3}, 0.1 \mathrm{~g} \mathrm{ZnSO}_{4} .7 \mathrm{H}_{2} \mathrm{O}, 0.03 \mathrm{~g} \mathrm{MnCl}_{2} .4 \mathrm{H}_{2} \mathrm{O}, 0.03 \mathrm{~g} \mathrm{Na}_{2} \mathrm{MoO}_{4} .2 \mathrm{H}_{2} \mathrm{O}, 0.02 \mathrm{~g} \mathrm{NiSO} .7 \mathrm{H}_{2} \mathrm{O}_{\text {, }}$ and $0.01 \mathrm{~g} \mathrm{CuSO}_{4} \cdot 5 \mathrm{H}_{2} \mathrm{O}$. The $\mathrm{BPM}$ is designed for use as the main medium for high cell density cultivation because of its simplicity, low cost ( 0.035-0.045 US \$ per liter), and high potential for industrial applications at the commercial scale of cell cultivation for the productions of varieties of bioproducts, from cell biomasses to fine biochemicals, e.g., pharmaceuticals. When compared to a laboratory medium, it costs $\sim 0.85$ US \$ per liter which is $\sim 25$ times higher.

\subsection{Preparations of Carbon Sources, Dextrin from Cassava Starch Liquefaction and Glucose from Further Saccharification of Dextrin}

It is important that an industrial application practice was implemented, in terms of potential raw material use and its preparation with in-house technologies. As plenty of a major C-source substrate, dextrin solution with a DE (dextrose equivalent) value of 25-40 was prepared by our own liquefaction method [16] using the in-house design and fabrication of a 200-L stirred-tank enzymatic hydrolysis bioreactor in the controlled optimum conditions. A 40\% (w/v) of cassava starch powder (3-Elephant Heads Brand (Chorchiwat Industry Co., Ltd. (CCW), Thailand) was suspended in distilled water and subsequently added with $0.1 \%(v / w)$ of $\alpha$-amylase (Spezyme Alpha, thermostable $\alpha$-amylase from Bacillus licheniformis with a minimum activity of 13,775 Units/g protein; DuPont Industrial Biosciences, Shanghai, China) per dry starch basis. The mixture was controlled at $85-90{ }^{\circ} \mathrm{C}, \mathrm{pH} 6.5$, and agitated with 2-Ekato Intermig, high-efficiency impellers at a speed of $125 \mathrm{rpm}$ for $3 \mathrm{~h} \mathrm{[17].} \mathrm{The} \mathrm{desired}$ concentrations of dextrin were adjusted by dilutions depending on each experimental condition.

A glucose solution with a DE of 95 was prepared by further hydrolysis called saccharification of the above dextrin solution. After liquefaction, the slurry of dextrin solution was cooled to $65^{\circ} \mathrm{C}$ and subsequently supplemented with a glucoamylase at $0.2 \%(v / w)$ (Distillase ASP, a blend of enzymes produced by $B$. licheniformis and Trichoderma reesei with a minimum activity of 580 units/g protein; DuPont Industrial Biosciences, Shanghai, China). The mixture was controlled at $65{ }^{\circ} \mathrm{C}, \mathrm{pH} 4.5$, and agitated at $100 \mathrm{rpm}$ for $20 \mathrm{~h}$. The desired concentrations of glucose were adjusted by dilutions on each experimental condition.

\subsection{The Effective BPM for Aerobic Batch Cultivation of S. cerevisiae}

The effective BPM for aerobic cultivation of $S$. cerevisiae was determined. The cultivations were undertaken in the 500-mL baffled flasks contained $100 \mathrm{~mL}$ of BPM with $20 \mathrm{~g} / \mathrm{L}$ of glucose supplemented with YE at a concentration of $0.3 \%(w / v)$ and another without the YE. They were compared with cultivation in the YPD medium. The initial pH of the three media was adjusted to 4.5 with $4 \mathrm{~N} \mathrm{NaOH}$ and $4 \mathrm{~N} \mathrm{HCl}$. After autoclaving and leaving to a temperature of $30^{\circ} \mathrm{C}$, the 5 -mL inoculant volumes (from Section 2.1) were inoculated into those culture media and incubated $30{ }^{\circ} \mathrm{C}$ in a rotary incubator shaker at a speed of $200 \mathrm{rpm}$ for $36 \mathrm{~h}$. The culture broth samples of $5 \mathrm{~mL}$ of each treatment were withdrawn every $6 \mathrm{~h}$, put on ice for $20 \mathrm{~min}$ to suddenly drop the temperature to $2{ }^{\circ} \mathrm{C}$ to stop cell activities before keeping at $5-10{ }^{\circ} \mathrm{C}$ in a refrigerator for further analyses of the $\mathrm{OD}_{600 \mathrm{~nm}}$, cell biomass, and reducing sugar concentrations. 


\subsection{The Addition of Yeast Extract as the Supplement in BPM}

From the above experimental result, in order to enhance more efficient utilization of BPM by $S$. cerevisiae, yeast extract (Hi-media, India), the major source of complex nutrients was supplemented into the BPM of $20 \mathrm{~g} / \mathrm{L}$ of glucose. The experiment was conducted using $500-\mathrm{mL}$ baffled flasks contained $100 \mathrm{~mL}$ of BPM supplemented with YE at concentrations of $0,0.3,0.6$, and $0.9 \%(w / v)$. The initial $\mathrm{pH}$ of the media was adjusted to 4.5 with $4 \mathrm{~N} \mathrm{NaOH}$ and $4 \mathrm{~N} \mathrm{HCl}$. After autoclaving and leaving to a temperature of $30^{\circ} \mathrm{C}$, the $5-\mathrm{mL}$ inoculant volumes (from Section 2.1) were inoculated into the four cultivation media and incubated at $30^{\circ} \mathrm{C}$ in a rotary incubator shaker at a speed of $200 \mathrm{rpm}$ for $36 \mathrm{~h}$. The culture broth samples of $5 \mathrm{~mL}$ were withdrawn every $6 \mathrm{~h}$ for the first $24 \mathrm{~h}$ and after that every $12 \mathrm{~h}$. They were put on ice for $20 \mathrm{~min}$ to suddenly drop the temperature to $2{ }^{\circ} \mathrm{C}$ to stop cell activities before keeping them at $5-10{ }^{\circ} \mathrm{C}$ for further analyses.

\subsection{The Comparison of Different Carbon Sources}

This was to compare the efficient utilization, by S. cerevisiae, of different C-sources, i.e., dextrin from cassava starch liquefaction, glucose from further dextrin saccharification (from Section 2.2), and the commercial pure glucose (D-glucose, Sigma-Aldrich). The experiment was conducted using 500-mL baffled flasks contained with $100 \mathrm{~mL}$ of BPM added with those C-sources at the same concentration of $20 \mathrm{~g} / \mathrm{L}$. The initial $\mathrm{pH}$ of the media was adjusted to 4.5 . After autoclaving and leaving to a temperature of $30{ }^{\circ} \mathrm{C}$, the 5-mL inoculant volumes (from Section 2.1) were inoculated into those three media. The cultivation conditions and the sample collections were undertaken with the same as above in Section 2.4. Noted, the concentrations of dextrin and glucose from dextrin saccharification were calculated from the initial concentration of starch hydrolysis at $40 \%(w / v)$. For stoichiometry, one gram of starch produces $1.11 \mathrm{~g}$ of glucose, thus the factor of 1.11 is used for the calculation of using glucose to meet the equimolar concentration of using dextrin at $20 \mathrm{~g} / \mathrm{L}$. So, glucose at a concentration of $22.22 \mathrm{~g} / \mathrm{L}$ should be used. When the starch hydrolysis is considered at $90 \%$ (based on $90 \%(w / w)$ pure starch content in cassava starch), the equimolar concentration of glucose to use is $19.98 \mathrm{~g} / \mathrm{L}$. This means that a $20 \mathrm{~g} / \mathrm{L}$ of dextrin from starch when completely hydrolyzed will produce $19.98 \mathrm{~g} / \mathrm{L}$ of glucose. This proves that the $20 \mathrm{~g} / \mathrm{L}$ of the three C-sources are comparable as they are all the same equimolar concentration of $111 \mathrm{mM}$ (millimolar) as the glucose at $20 \mathrm{~g} / \mathrm{L}$ (calculated from $(20 / 180.156) \times 1000=111 \mathrm{mM})$.

\subsection{The High Concentrations of Dextrin for S. cerevisiae Cultivation in the 5-L Bioreactors}

The larger-scale cell cultivation in the accurate control conditions using bioreactor makes the results approaching more scalability. The 5 -L bioreactors of $0.15 \mathrm{~m}$ in diameter and $0.35 \mathrm{~m}$ height fit with 2 Rushton turbine impellers of $0.065 \mathrm{~m}$ were operated. This experiment was carried out to investigate the optimal-high concentration of dextrin to use as the C-source instead of glucose by S. cerevisiae cultivation in the 5-L bioreactor with 3-L working volume. This experiment was carefully developed from a normal batch procedure to the intensive batch cultivation technique using four intense parameters: (i) high concentrations of BMP, (ii) high concentrations of dextrin, (ii) high agitation rates, and (iv) high aeration rates. They were proportionally increased when the concentrations of dextrin used were increasingly changed (Table 1). This experiment was designed to achieve high cell biomass yield related to stoichiometry. The higher the concentrations of BPM and dextrin, the higher the intensities of aeration and agitation were operated with the optimum cultivation conditions that could produce the higher biomass yields. Those parameters effect efficient mass transfers and balance the uses of substrates, i.e., carbon and nitrogen sources; $\mathrm{O}_{2}$ and inorganic salts to produce cell biomass at high-density concentrations. This is superior to the conventional fed-batch technique in many ways as mentioned before. 
Table 1. The designed experimental parameters and conditions for normal batch and intensive multiple sequential batches for cultivations of S. cerevisiae in 5-L bioreactors to produce cell biomass at high density concentrations. \# Molar concentrations of dextrin were calculated on the basis of $90 \%(w / w)$ glucose content of them.

\begin{tabular}{cccccccc}
\hline Treatments & $\begin{array}{c}\text { Dextrin } \\
\text { Conc. } \\
\text { (g/L) }\end{array}$ & $\begin{array}{c}\text { \# Glucose } \\
\text { Conc. } \\
\text { (mM) }\end{array}$ & $\begin{array}{c}\text { Yeast } \\
\text { Extract } \\
\text { (g/L) }\end{array}$ & $\begin{array}{c}\text { BPM } \\
\text { Conc. }\end{array}$ & $\begin{array}{c}\text { Agitation Rates by } \\
\text { Controlling Power } \\
\text { Input (W/kg) }\end{array}$ & $\begin{array}{c}\text { Agitation } \\
\text { Speeds } \\
\text { (rpm) }\end{array}$ & $\begin{array}{c}\text { Aeration } \\
\text { Rates } \\
\text { (vvm) }\end{array}$ \\
\hline Normal & 30 & 150 & 3 & $1 \times$ & 1 & 500 & 1 \\
Intensive I & 60 & 300 & 6 & $2 \times$ & 2 & 600 & 2 \\
Intensive II & 90 & 450 & 9 & $3 \times$ & 3 & 700 & 3 \\
Intensive III & 120 & 600 & 12 & $4 \times$ & 4 & 800 & 4 \\
\hline
\end{tabular}

A $3 \mathrm{~L}$ of BPM was prepared at a concentration of $1 \times$, put into a 5-L bioreactor, and sterilized at $121{ }^{\circ} \mathrm{C}$ under $15 \mathrm{lb} / \mathrm{in}^{2}$ pressure for $25 \mathrm{~min}$ in an autoclave. A dextrin solution of $40 \%(w / v)$ from cassava starch liquefaction was separately sterilized at $110^{\circ} \mathrm{C}$ under $15 \mathrm{lb} / \mathrm{in}^{2}$ for $10 \mathrm{~min}$. Its $225 \mathrm{~mL}$ was added into the bioreactor to the designed concentration of $30 \mathrm{~g} / \mathrm{L}$ (equivalent to a concentration of $150 \mathrm{mM}$ of glucose content) and YE was added at a concentration of $3 \mathrm{~g} / \mathrm{L}$. The cultivation conditions were set and controlled at $30^{\circ} \mathrm{C}$, $\mathrm{pH}$ of 4.5 by $4 \mathrm{~N} \mathrm{HCl}$ and $4 \mathrm{~N} \mathrm{NH}_{4} \mathrm{OH}$ solutions, 1 vvm airflow rate, and $1 \mathrm{~W} / \mathrm{kg}$ of power input, $\bar{\varepsilon}_{T}$ at an impeller speed of $500 \mathrm{rpm}$ throughout the run. After they were well controlled and reached the designed conditions, a $150 \mathrm{~mL}$ of $S$. cerevisiae inoculum (from Section 2.1) was inoculated into the bioreactor (at a concentration of $5 \% v / v$ ). For other treatments, the concentrations of dextrin in the cultures were at 60,90 , and $120 \mathrm{~g} / \mathrm{L}$ (equivalent to concentrations of 300, 450, and $600 \mathrm{mM}$ of glucose content, respectively). The YE was added at the concentrations of 6,9 , and $12 \mathrm{~g} / \mathrm{L}$, respectively giving the same $\mathrm{YE} /$ dextrin fraction with a value of 0.1 . They were proportional to the increase in BPM concentration, agitation speed, and aeration rate as in Table 1. to achieve higher biomass yields. During cultivations, the culture broth samples of $10 \mathrm{~mL}$ of each treatment were withdrawn every $6 \mathrm{~h}$ for $30 \mathrm{~h}$. Again, they were put on ice for $20 \mathrm{~min}$ to suddenly drop the temperature to $2{ }^{\circ} \mathrm{C}$ and stop cell activities before keeping at $-20{ }^{\circ} \mathrm{C}$ for further analyses.

\subsection{The Development from Batch to the Intensive Multiple Sequential Batch (IMSB) Technique to Achieve High Cell Density Concentration}

This experiment was developed from a single batch to the intensive multiple sequential batches (see [17]) to achieve a high cell biomass with a high productivity. A $3 \mathrm{~L}$ of BPM was prepared at a concentration of $3 \times$ put into a 5 -L bioreactor and sterilized at $121^{\circ} \mathrm{C}$ under $15 \mathrm{lb} / \mathrm{in}^{2}$ pressure for $25 \mathrm{~min}$. A dextrin solution of $40 \%(w / v)$ was separately sterilized as above and its $675 \mathrm{~mL}$ was added into the bioreactor to the designed concentration of $90 \mathrm{~g} / \mathrm{L}$ for 3 - $\mathrm{L}$ working volume. The cultivation conditions were controlled at $30^{\circ} \mathrm{C}$ and $\mathrm{pH} 4.5 ; 3 \mathrm{vvm}$ airflow rate and $3 \mathrm{~W} / \mathrm{kg} \bar{\varepsilon}_{T}$ at the impeller speed of $700 \mathrm{rpm}$. After they were well controlled and reached the designed conditions. To increase the growth rate higher than the experiment in Section 2.6 ( $30 \mathrm{~h}$ of cultivation time course), a higher concentration of inoculum culture was used. A $150 \mathrm{~mL}$ of $S$. cerevisiae inoculum of an $\mathrm{OD}_{600 \mathrm{~nm}}$ of $\sim 15-20$ from $24 \mathrm{~h}$ culture was inoculated into the bioreactor (at a concentration of $5 \% v / v$ ) and grown for $24 \mathrm{~h}$ of the initial (first) batch.

Following the first batch, the intensive multiple sequential batch operations were further continually repeated for four more cycles without newly batch up and sterilization. When each batch was completed, a major culture broth was discharged using a peristaltic pump, leaving only a $150 \mathrm{~mL}$ to be the starter inoculum for the next batch (at $5 \% \mathrm{v} / \mathrm{v})$. Unlike the initial batch, the inoculants of the batch cycles 2-5 were the high cell density starters (the culture broths left from the prior batches).

During the time of the first batch cultivation, a further $3000 \mathrm{~mL}$ of the fresh medium of the same components and concentration was prepared. Dextrin solution was again prepared. It was sterilized separately and then newly added into the same bioreactor after the first culture broth withdrawal. The second cultivation process was again restarted under the same controlled conditions. 
The cultivation process was continually repeated for five cycles. Along with the five cultivations, the culture broth samples of $10 \mathrm{~mL}$ were withdrawn every $6 \mathrm{~h}$ for $24 \mathrm{~h}$. They were put on ice for $20 \mathrm{~min}$ for the same reason above and kept at $-20^{\circ} \mathrm{C}$ for further analyses.

\subsection{Cell Growth Determination by Measuring Optical Density (OD) and Dry Cell Weight (DCW)}

The growth during the cultivations of $S$. cerevisiae was determined by measuring absorbance and cell biomass concentration. For the former, a $1 \mathrm{~mL}$ of each culture broth sample was diluted 10 or 100 times with distilled water at an appropriate concentration and measured the absorbance at an optical density of $600 \mathrm{~nm}\left(\mathrm{OD}_{600 \mathrm{~nm}}\right)$ using a spectrophotometer. For the latter, a $1.5 \mathrm{~mL}$ of each culture broth sample was put into the micro-centrifuge tube and centrifuged at 10,000 rpm for $10 \mathrm{~min}$. The supernatant was decanted and then the tube was added with a more $1.0 \mathrm{~mL}$ distilled water and re-centrifuged to wash the cells. The cell samples were dried at $80^{\circ} \mathrm{C}$ for $24 \mathrm{~h}$ and weighed. Both methods were used in order to recheck each other for confident reliability.

\subsection{Reducing Sugar Analysis}

Glucose concentrations of the culture broth samples during cultivations were analyzed as the reducing (residual) sugar $\left(\mathrm{G}_{\mathrm{l}}\right)$ quantities in the culture using the DNS method [18]. The 1-mL volumes of DNS reagent were added to test tubes each contained a $1 \mathrm{~mL}$ of $1 / 10$ diluted culture broth sample. The mixtures were incubated in a boiling water bath at $95{ }^{\circ} \mathrm{C}$ for $5 \mathrm{~min}$ and then transferred into a cold bath at $5{ }^{\circ} \mathrm{C}$ for $5 \mathrm{~min}$ to stop the reaction. Then, each tube was added with a $10 \mathrm{~mL}$ of distilled water and mixed well before measuring the absorbance at $520 \mathrm{~nm}$ by a spectrophotometer. The quantities of reducing sugar were measured as the glucose concentration by comparison with the standard plot of known glucose concentrations of $0,0.2,0.4,0.6,0.8$, and $1.0 \mathrm{~g} / \mathrm{L}$ reacted with the DNS reagent and following the same procedure to measure the absorbance.

To verify the DNS assay method is significantly accurate. The concentrations of glucose standard solutions from 0 to $1.0 \mathrm{~g} / \mathrm{L}$ as above were analyzed both by the DNS assay and by the High Performance Liquid Chromatography (HPLC) method. The HPLC (KNAUER Smartline, Berlin, Germany) with a refractive index (RI) detector (KNAUER Smartline 2300, Berlin, Germany) and a Eurokat H vertex column (KNAUER, Berlin, Germany) was used. Eluent of $0.01 \mathrm{~N}$ sulfuric acid solution at a flow rate of $0.8 \mathrm{~mL} / \mathrm{min}$ was utilized. The analyses were performed at $60^{\circ} \mathrm{C}$. The samples were 10 -fold diluted, filtered through $0.45-\mu \mathrm{m}$ filters, and injected into the column with an amount of $20 \mu \mathrm{L}$. The results of both methods were compared and given no significant difference. The two might deviate from each other with a value of $\leq 5 \%$ deviation. Thus, the DNS method was used to quantify the concentration of glucose along with the yeast cell cultivations.

\subsection{Total Sugar Analysis}

Total sugars $\left(\mathrm{S}_{\mathrm{T}}\right)$ mean all the concentrations of C-sources, i.e., free residual glucose $\left(\mathrm{G}_{\mathrm{l}}\right)$ plus dextrin (Dx) left in the culture of which dextrin in the mixture of cell culture was completely hydrolyzed by a strong acid to release all glucose molecules, and then glucose from both sources in the same mixture was measured as the total sugar or total glucose. Thus $\mathrm{S}_{\mathrm{T}}$ is the glucose from hydrolyzed $\mathrm{Dx}$ plus $G_{1}$. The total sugar of culture broth during cell growth was analyzed by sulfuric acid hydrolysis method modified from [16]. The 1-mL samples of culture broth in micro-tubes were centrifuged at 10,000 rpm for $10 \mathrm{~min}$. The supernatants of $0.5 \mathrm{~mL}$ were transferred into $20-\mathrm{mL}$ test tubes. Then 2-mL volumes of $2 \mathrm{~N} \mathrm{H}_{2} \mathrm{SO}_{4}$ solution were added, mixed well, and capped. Test tubes with the mixture were boiled in a water bath at $95^{\circ} \mathrm{C}$ for $30 \mathrm{~min}$. The neutralizations were done with the addition of $4 \mathrm{~N}$ $\mathrm{NaOH}$ and re-centrifugation to precipitate the residues. The supernatants were used to measure the total sugar by the DNS method. 


\subsection{Quantitative Analyses of Total Sugar and Reducing Sugar (glucose) during Cell Cultivations}

Again, total sugar $\left(\mathrm{S}_{\mathrm{T}}\right)$ means the amount of dextrin $(\mathrm{Dx})$ plus residual glucose or glucose left $\left(G_{l}\right), S_{T}=D x+G_{l}$ in the cultures during cell cultivation. Thus, the concentration of dextrin in culture broth is $S_{T}$ minus $G_{l}$, as $D x=S_{T}-G_{l}$. As we know the initial concentration of C-source, $\left(C_{i}\right)$, thus we know the concentration and the utilization rate of $G_{l}$, and also know those of the $S_{T}$. As a result, we know the concentration and the degradation rates Dx. So, we know the rates of change of all the carbon components in the culture system through the cultivation time course (Section 2.12). We obviously see gradual hydrolysis or degradation of the dextrin oligomer to release free glucose molecules continuously into the culture and subsequently gradual assimilation of glucose into the yeast cells. This phenomenon essentially regulates the fed-batch strategy at the cell level. So, we have herein invented the new technical term "fed-batch at cell level" (FBC). The FBC importantly prevents the cell cultivation system from the Crabtree effect. As a result, it promotes cell growth at a high rate, and enables the use of a very high concentration of $\mathrm{C}$-source with just the aerobic batch mode whilst in principle this cannot be done using glucose and/or sucrose. In the laboratories to the pilot scales, many researchers increased the nutrients, i.e., proteins, minerals, growth factors, etc. in the media and increased the impeller speeds and the airflow rates, but they exceeded the economically scalable values.

\subsection{Engineering Mass Balances' Method to Quantify the Unknown Values of Dextrin and Glucose Uptake}

This is the "state-of-the-art" method. As a limitation of the HPLC method to analyze the quantities of dextrin oligomer at a time of such a wide range of Dp (Degree of polymerization of carbon atoms), e.g., from $C_{18}, C_{17}, C_{16} \ldots C_{10}, C_{9}, C_{8}, C_{7} \ldots$ to $C_{1}$, thus we use the Biochemical Chemical Engineering mass balances' technique. In Section 2.11, with the use of the mass balances' model from the overall mass balance equation, $C_{i}=G_{u}+S_{T} \ldots$ (Equation (1)), where $G_{u}$ is the total glucose uptake, and the component mass balances of $S_{T}=D x+G_{l} \ldots$. (Equation (2)), the concentrations of all the components can be calculated. Furthermore, the utilization rates, $r$, of each component can also be calculated as, $r S_{T}=\frac{d S_{T}}{d t}$ is the rate of total sugar degradation; $r G_{u}=\frac{d G_{u}}{d t}$ is the rate of overall glucose uptake; $r G_{l}=\frac{d G_{l}}{d t}$, is the rate of residual glucose utilization; $r D x=\frac{d D x}{d t}$ is the rate of dextrin degradation. Significantly, this biochemical engineering mass balance model, $r S_{T}=r G_{u}=r G_{l}+r D x \ldots$ (Equation (3)). This clearly again proves and confirms the "fed-batch at cell level", the FBC phenomenon.

\subsection{Statistical Analysis}

The statistical analyses were done with the one-way analysis of variance (ANOVA) and the differences of the treatment mean values from three replications (each experiment was done in 3 replicates) were compared with the Tukey's range test method at $p$-value $\leq 0.05$ using a software Minitab version 17. All the experimental result data were presented as the graphical plots using the mean values together with the error bars of standard deviations. The kinetic results are presented in the tables.

\subsection{Growth Kinetic Parameters' Calculations}

The five growth kinetic parameters were calculated using experimental data, i.e., cultivation time, $\mathrm{t}(\mathrm{h})$, cell biomass concentration, $x(\mathrm{~g} / \mathrm{L})$, and substrate use, $s(\mathrm{~g} / \mathrm{L})$. (i) The specific growth rate, $\mu\left(\mathrm{h}^{-1}\right)$ is calculated from, $\mu=\frac{d l n x}{d t}$, where the differential natural log of $x$ is divided by the time change. (ii) The productivity or production rate of cell biomass, $r_{x}(\mathrm{~g} / \mathrm{L} / \mathrm{h})$ is $r_{x}=\frac{d x}{d t}$. (iii) The utilization rate of substrate, $r_{s}(\mathrm{~g} / \mathrm{L} / \mathrm{h})$ is from $r_{s}=\frac{d s}{d t}$, where $s$ can be all types of the sugar components, i.e., total sugar $\left(S_{T}\right)$, glucose uptake $\left(G_{u}\right)$, glucose residual $\left(G_{1}\right)$, and dextrin $(D x)$, (iv) The cell yield coefficient, $Y_{x / s}(g / g)$ is from $Y_{x / s}=\frac{\Delta x}{\Delta s}$, where $\Delta x$ is the cell biomass produced $(\mathrm{g} / \mathrm{L})$ and $\Delta s$ is the substrate utilized $(\mathrm{g} / \mathrm{L})$. (v) The production efficiency, $E f(\%)$ is from $E f=\frac{Y_{x / s}}{Y_{x / s}} \times 100$, where $Y_{x / s}$ is from the experiment and $Y_{x / s}^{\prime}$ is from the theoretical yield coefficient or stoichiometry [15,19]. One gram of commercial glucose or glucose from dextrin could produce a cell biomass of $0.53 \mathrm{~g},\left(\mathrm{Y}_{\mathrm{x} / \mathrm{s}_{\mathrm{glu}}}=0.53 \mathrm{~g} / \mathrm{g}\right)$ and one gram of 
$\mathrm{YE}$ could additionally produce a cell biomass of $\sim 0.6-0.7 \mathrm{~g},\left(\mathrm{Y}_{\mathrm{x} / \mathrm{s}_{\mathrm{YE}}}=0.6-0.7 \mathrm{~g} / \mathrm{g}\right)$. When they are mixed in the medium, the $Y^{\prime}{ }_{x / s}$ was calculated based on the fraction of their components.

\subsection{Calculation of the Designed Impeller Speeds}

For fluid dynamics in a stirred-tank bioreactor [19-21], the power $\mathrm{P}(\mathrm{W})$ is calculated from $P=n P o_{g} \rho N^{3} D^{5}$, where $n$ is the number of impellers of 2 for 5 -L bioreactor, $P o_{g}$ is the power number of 2.4, (no unit or dimensionless) for fluid with air sparging of Rushton turbine impeller in the bioreactor, $\rho$ is the culture broth density $\left(\mathrm{kg} / \mathrm{m}^{3}\right), N$ is the impeller speed (rps), and $D$ is the impeller diameter of $0.065(\mathrm{~m})$. The power input or energy dissipation rate per unit mass, $\bar{\varepsilon}_{T}(\mathrm{~W} / \mathrm{kg})$ is calculated from $\bar{\varepsilon}_{T}$ or $\frac{P}{\rho V}=\frac{n P_{g} \rho N^{3} D^{5}}{\rho V}$, where $V$ is the culture broth volume $\left(\mathrm{m}^{3}\right)$. Thus, the designed impeller speeds, $N$ of the power inputs $1,2,3$, and $4(\mathrm{~W} / \mathrm{kg})$ are calculated from $N=\left(\frac{\bar{\varepsilon}_{T} V}{n \operatorname{Pog}_{g} D^{5}}\right)^{1 / 3}$. These both kinetic and fluid dynamic parameters from the laboratory experiments are very crucial for the scale-up of further microbial cell cultivations both at the pilot and especially at the industrial scales. That is the foreseen reason why we designed the impeller speeds based on the power input rather than just the speed in rpm (Table 1).

\section{Results and Discussion}

\subsection{The Effective BPM for S. cerevisiae Cultivation}

A batch production medium (BPM) is a chemically defined minimal medium formulated here by our laboratory as a high potential medium for high cell density cultivation in the industry. The effectiveness of the BPM supplemented with YE was higher than that of the standard YPD complex medium for S. cerevisiae cultivation (Figure 1). At all the same glucose concentration of $20 \mathrm{~g} / \mathrm{L}(111 \mathrm{mM})$, the BPM with $0.3 \%(w / v)$ of YE significantly produced yeast cell biomass at a concentration of $7.67 \mathrm{~g} / \mathrm{L}$, the YPD medium produced it at $6.93 \mathrm{~g} / \mathrm{L}$, while the BPM without YE could produce it at only $3.30 \mathrm{~g} / \mathrm{L}$. The sole BPM is the lowest effective medium because it is the defined minimal medium containing only the satisfied defined nutrients, inorganic salts, and some trace elements. It lacks necessary nutrients, i.e., proteins, minerals, and growth factors, i.e., vitamins. As the microorganism growth requires major nutritive components, i.e., carbohydrate as an energy C-source and proteins as the cell components, they additionally still require peptides, amino acids, fatty acids and lipids, nucleic acids, inorganic salts, trace elements, and vitamins which are the precursors for numerous co-factors [22]. So, when the YE was added into the BPM, it importantly promotes $S$. cerevisiae cell growth and biomass production. It was observed from the increase in cell biomass at the final concentration of $7.67 \mathrm{~g} / \mathrm{L}$, which was higher than those of the two (Figure 1).

Yeast extract contains abundant components (\% w/w) of carbohydrates and derivatives $(\sim 10-35 \%)$, proteins $(\sim 45-50 \%)$ and free amino acids $(\sim 8-15 \%)$, vitamin derivatives $(\sim 5-10 \%)$, minerals and trace elements $(\sim 5-10 \%)$, nucleotides $(\sim 5-15 \%)$, and fat $(\sim 3-10 \%)$, which are necessary for microbial cell growth [23]. The BPM defined medium added with the YE is actually called "semi-defined medium". The medium was mostly composed of the defined components with only one or two complex nutrients [24]. In this research work, it was the effective medium for yeast cell cultivation because it enhanced higher cell biomass concentration than that of the standard medium (YPD). The BPM can be both defined and semi-defined medium that has many advantages to be used both in the laboratory and at the industrial scale. It is much cheaper ( $\sim 0.035-0.045$ US \$ per liter), when compared to a laboratory medium of $\sim 0.85$ US $\$$ per liter which is $\sim 25$ times higher. The BPM is simpler to be produced and easier to be controlled in fermentation and downstream processes effecting lower cost of investment [25]. 

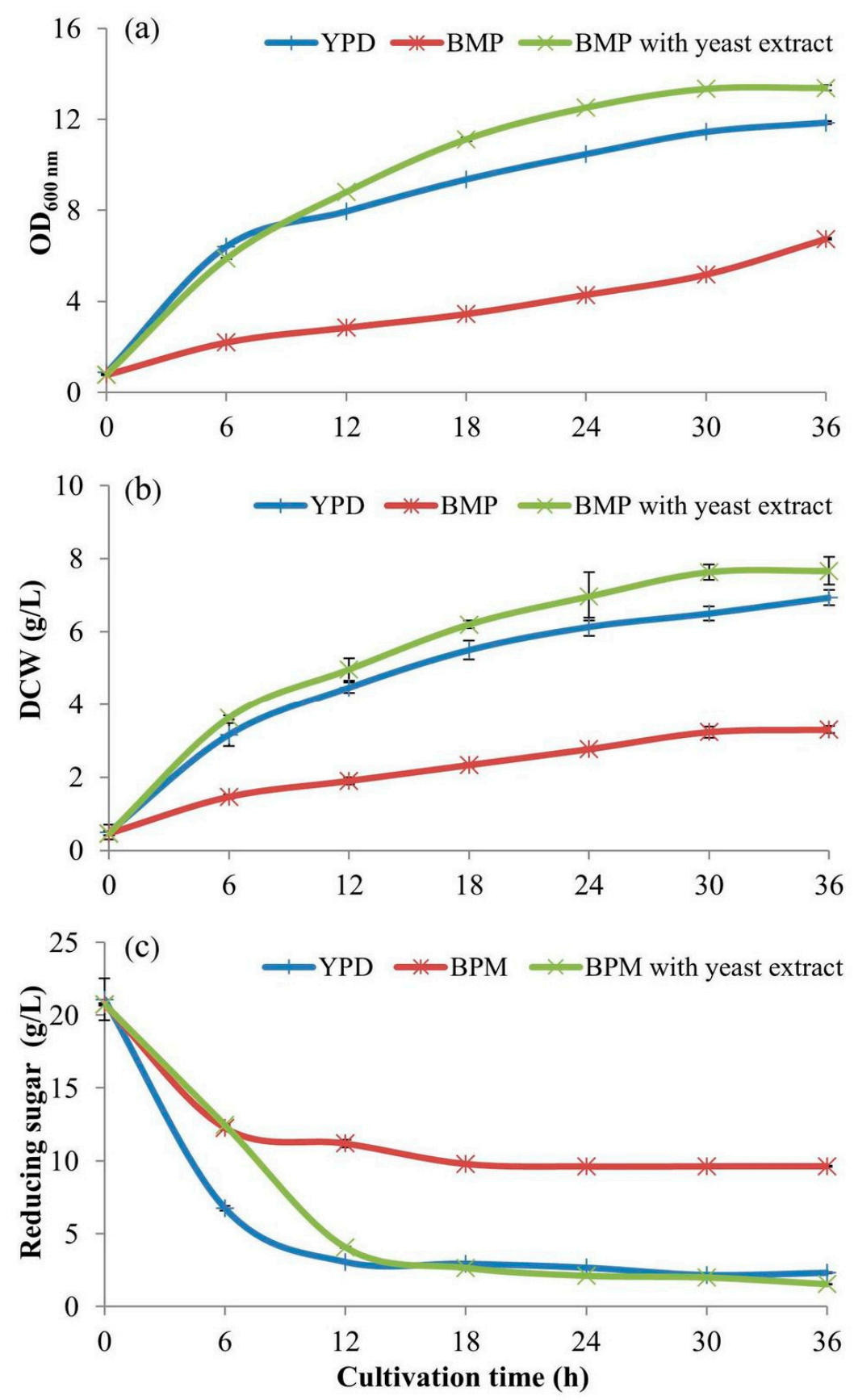

Figure 1. Growth (a) $\mathrm{OD}_{600 \mathrm{~nm}}$; (b) dry cell weight, and (c) glucose (reducing sugar) used during cultivations of S. cerevisiae in shake flasks with different media, YPD (Yeast Peptone Dextrose) a standard medium for yeast culture, BPM (Batch Production Medium) with yeast extract (YE) and BPM without $\mathrm{YE}$ as a control treatment. The BPM was formulated here for economic reasons and potent industrial use. Note: As standard deviation values are very small, error bars in Figures (a) and (b) are somewhat invisible.

\subsection{The Addition of Yeast Extract as the Supplement to Improve the BPM for Yeast Cell Cultivation}

As yeast extract significantly promotes yeast cell growth, its minimal optimum concentration herein for aerobic cultivation of S. cerevisiae is at $0.3 \%(w / v)$ (Figure 2). This treatment produced cell biomass at a concentration of $10.96 \mathrm{~g} / \mathrm{L}$ at $18 \mathrm{~h}$ with a specific growth rate, $\mu$ at $0.15 \mathrm{~h}^{-1}$, a cell yield coefficient, $Y_{x / \mathrm{s}}$ of $0.53 \mathrm{~g} / \mathrm{g}$, a cell biomass production rate, $r_{x}$ at $0.61 \mathrm{~g} / \mathrm{L} / \mathrm{h}$, and a substrate consumption rate, $r_{s}$ at $0.94 \mathrm{~g} / \mathrm{L} / \mathrm{h}$ with an efficiency of $95.98 \%$. This also reduced cultivation time and increased 
cell biomass when compared to the control treatment of the cultivation without the addition of YE $(0 \% w / v)$. However, the increase in YE concentrations at $0.6 \%$ and $0.9 \%(w / v)$ performed no significant difference in biomass concentration $(x)$ and specific growth rate $(\mu)$, while the yield coefficient $\left(Y_{x / s}\right)$ and the cultivation efficiency $(E f)$ of $0.3 \%(w / v)$ YE addition were higher (Table 2).
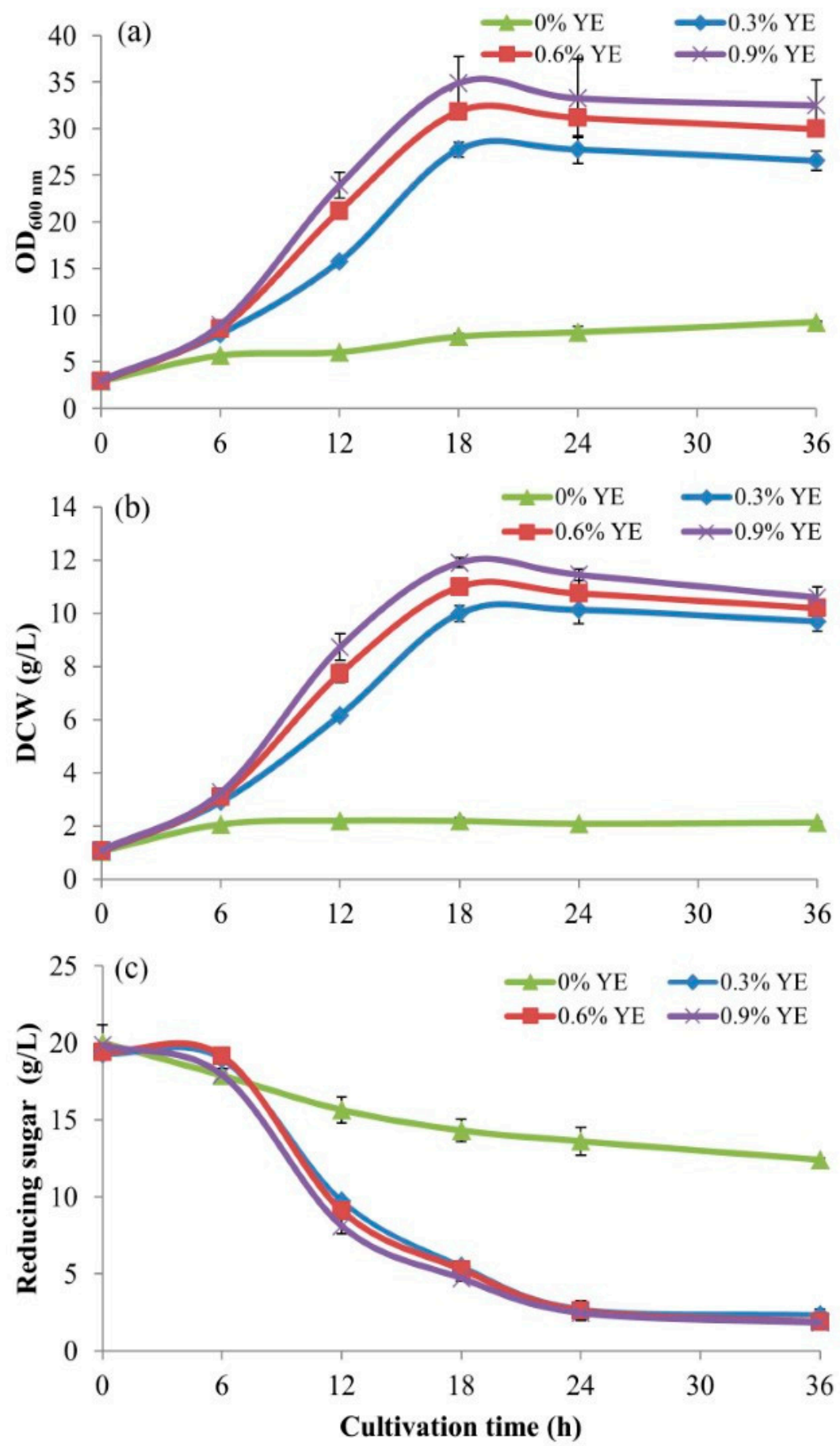

Figure 2. Growth (a) $\mathrm{OD}_{600 \mathrm{~nm}}$; (b) dry cell weight, and (c) glucose utilization during cultivations of $S$. cerevisiae in shake flasks using BPM with $20 \mathrm{~g} / \mathrm{L}$ of glucose, supplemented with yeast extract (YE) at different concentrations $(\% w / v)$.

Normally, both anabolic and catabolic pathways of S. cerevisiae require amino acids such as Ser, Gly, Cys, Tyr, Trp, and others in certain concentrations which are sufficient but not excessive. These are present in YE. These results suggest that the BPM lacks amino acids, essential nutrients, and other 
growth factors. The addition of YE at $0.3 \%(w / v)$ can supply those essential sources for yeast cell growth to produce cell biomass at a high concentration. Although more increasing it to concentrations of $0.6 \%$ and $0.9 \%(w / v)$ did not result in the increasing cell biomass, but these concentrations did not exceed the inhibiting value to yeast cells. Although it was reported that peptone and YE did not have any significant effect on cell growth or sugar consumption [26]; however, with the supplement of YE at a concentration of $6 \mathrm{~g} / \mathrm{L}$ into the medium, ethanol concentration was slightly higher than those of the supplements of $Y E$ at 3 and $9 \mathrm{~g} / \mathrm{L}$ [27].

Table 2. Growth kinetic parameters of $S$. cerevisiae cultivations in shake flasks using BPM medium with $20 \mathrm{~g} / \mathrm{L}$ glucose and supplemented with yeast extract at different concentrations.

\begin{tabular}{cccccccc}
\hline YE Conc. & YE/Glucose & $\mathbf{x}$ & $\mu$ & $\boldsymbol{Y}_{x / \mathbf{s}}$ & $r_{\boldsymbol{x}}$ & $r_{s}$ & Efficiency \\
\hline $\mathbf{( \% )}$ & Fraction & $\mathbf{( g / L )}$ & $\left.\mathbf{( h}^{-\mathbf{1}}\right)$ & $\mathbf{( g / g )}$ & $(\mathrm{g} / \mathrm{L} / \mathbf{h})$ & $(\mathrm{g} / \mathrm{L} / \mathbf{h})$ & $\mathbf{( \% )}$ \\
\hline $\mathbf{0 . 0}$ & 0.00 & $2.19^{\mathrm{b}}$ & $0.11^{\mathrm{c}}$ & $0.29^{\mathrm{c}}$ & $0.18^{\mathrm{c}}$ & $0.36^{\mathrm{c}}$ & $54.72^{\mathrm{d}}$ \\
$\mathbf{0 . 3}$ & 0.15 & $10.96^{\mathrm{a}}$ & $0.15^{\mathrm{ab}}$ & $0.53^{\mathrm{a}}$ & $0.61^{\mathrm{b}}$ & $0.94^{\mathrm{b}}$ & $95.98^{\mathrm{a}}$ \\
$\mathbf{0 . 6}$ & 0.30 & $11.42^{\mathrm{a}}$ & $0.17^{\mathrm{a}}$ & $0.48^{\mathrm{b}}$ & $0.63^{\mathrm{ab}}$ & $1.12^{\mathrm{b}}$ & $84.32^{\mathrm{b}}$ \\
$\mathbf{0 . 9}$ & 0.45 & $11.91^{\mathrm{a}}$ & $0.17^{\mathrm{a}}$ & $0.44^{\mathrm{b}}$ & $0.66^{\mathrm{a}}$ & $1.35^{\mathrm{a}}$ & $75.50^{\mathrm{c}}$
\end{tabular}

Statistic comparisons of those mean values within their own columns (among yeast extract concentrations) at $p$-values of $\leq 0.05$ show different characters, $a, b$, and c, which indicate statistically significant differences.

\subsection{Different Carbon Sources for the Yeast Cultivation}

Type and concentration of C-sources in culture media effect to cell biomass and product formation especially for high cell density cultivation. Each microorganism requires and has some limitations on the type and its concentration. In general, glucose and sucrose are used for aerobic batch cultivations of microorganisms in bioreactors of every scale at a limited concentration of $\leq 40-50 \mathrm{~g} / \mathrm{L}$ [17]. Glucose is very effective and is the most popular $\mathrm{C}$-source because it supports fast growth as it is a single molecule and easy to consumption first. It is the initial substrate and the precursor of the main pathways. However, glucose cannot be used at too a high concentration as it is easily assimilated into the cells, causing its accumulation and congestion. This usually causes the Crabtree effect that inhibits cell growth. Because of the insufficiency of dissolved oxygen concentration, and the limitation of the bioreactor operation, the yeast cells produce ethanol and the bacterial cells produce acetate, the toxic by-products, instead of going through ATP-producing pathways. In this situation, cells stop growing and consequently producing low cell biomass. Glycerol is an alternative popular C-source because of its advantages, e.g., a high degree of reduction (4.67) per carbon when compared to that of glucose with a value of 4 [14] and prevention of cell system from the Crabtree effect [19]. There was a study on recombinant $S$. cerevisiae cultivation to obtain high cell density using glycerol as a substrate in the fed-batch mode with a feeding strategy based on an online response of the culture $\mathrm{pH}$ to the glycerol consumption [28].

Actually, yeast $S$. cerevisiae can utilize many different C-sources, such as glucose, fructose, galactose, mannose, and other alternative sources of the disaccharide, e.g., maltose and sucrose $[29,30]$. Glucose is the most popular C-source for yeast cultivation for the production of biological products as it provides fast growth other than other sugars. It is consumed first in sugar mixtures. However, it causes some limitations and problems as discussed above. To overcome those limitations, this research was challenged to the use of dextrin, the oligomer of glucose, the primary hydrolysate from cassava starch liquefaction as a new potential C-source to substitute glucose for S. cerevisiae cultivation.

Figure 3 and Table 3 show that yeast S. cerevisiae could not use sole dextrin as a C-source because it lacks hydrolase enzyme to degrade dextrin oligomer and release free glucose molecules. It could produce cell biomass at a concentration of only $4.52 \mathrm{~g} / \mathrm{L}$. When a glucoamylase enzyme was added together with dextrin into the BPM, dextrin was hydrolyzed to release glucose, and glucose was subsequently utilized by the yeast. This treatment produced cell biomass at a concentration of $9.51 \mathrm{~g} / \mathrm{L}$ within $24 \mathrm{~h}$ at a specific growth rate, $\mu$ of $0.11 \mathrm{~h}^{-1}$, a cell yield coefficient, $Y_{x / \mathrm{s}}$ of $0.47 \mathrm{~g} / \mathrm{g}$, a cell biomass 
production rate at $0.40 \mathrm{~g} / \mathrm{L} / \mathrm{h}$ and a substrate utilization rate at $0.74 \mathrm{~g} / \mathrm{L} / \mathrm{h}$ with an efficiency of $85.12 \%$. These values are close to those of the cultivation with glucose (Table 3).
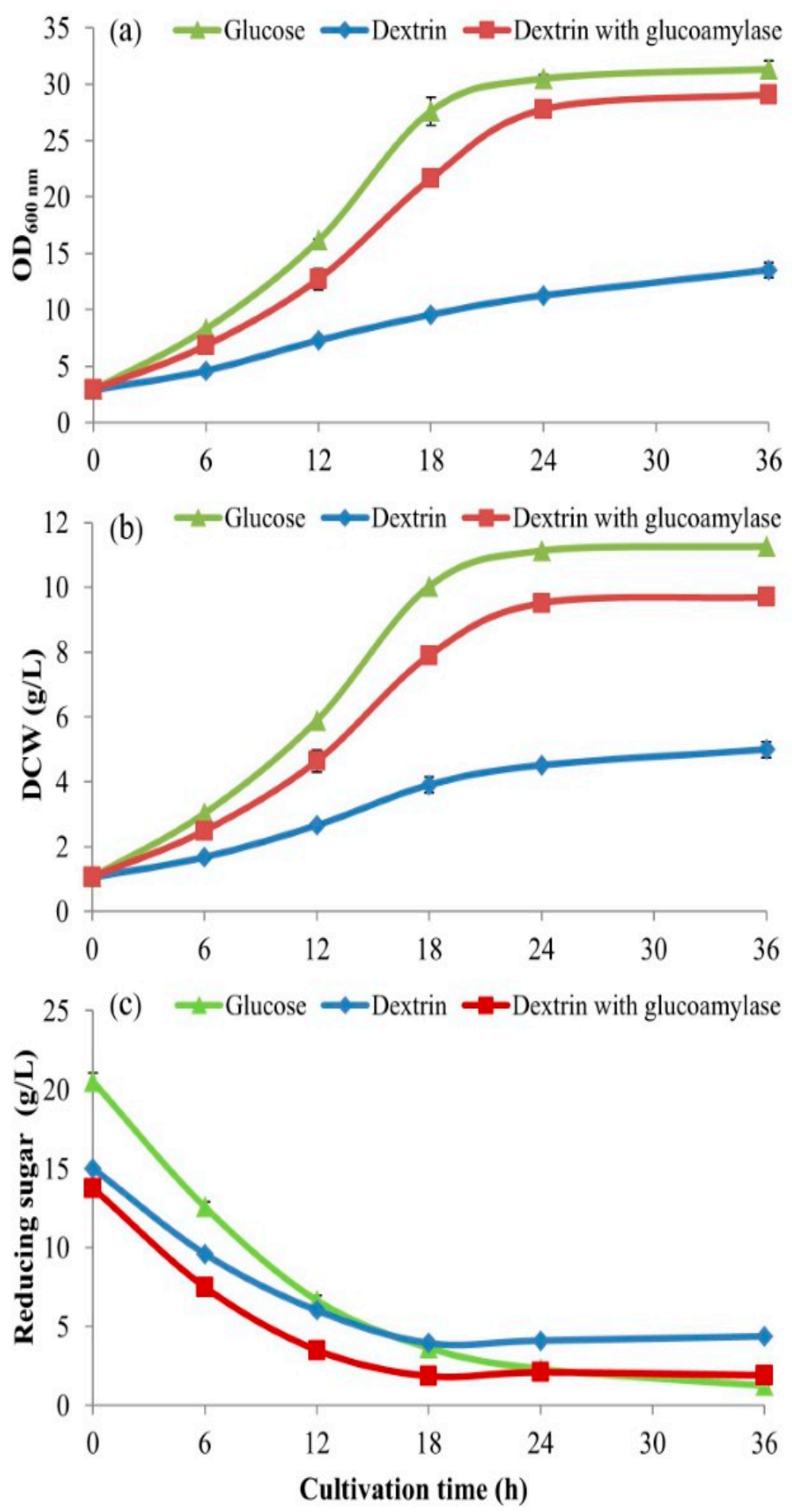

Figure 3. Growth (a) $\mathrm{OD}_{600 \mathrm{~nm}}$; (b) dry cell weight, and (c) substrates utilized during cultivations of S. cerevisiae in shake flasks using BPM with $20 \mathrm{~g} / \mathrm{L}$ of different carbon sources, each supplemented with $0.3 \%(w / v)$ of yeast extract to compare with the use of glucose and select the most potential C-source for larger-scale and industrial cultivations; Note: As standard deviation values are very small, error bars in Figures might be invisible. 
Table 3. Growth kinetic parameters of $S$. cerevisiae cultivations in shake flasks using BPM medium with $20 \mathrm{~g} / \mathrm{L}$ of different carbon sources (at the same equimolar concentration of $111 \mathrm{mM}$ ), each supplemented with yeast extract at $0.3 \%(w / v)$.

\begin{tabular}{ccccccc}
\hline \multirow{2}{*}{ Carbon Sources } & $\mathbf{x}$ & $\mu$ & $Y_{x / s}$ & $r_{x}$ & $r_{s}$ & Efficiency \\
\cline { 2 - 6 } & $(\mathrm{g} / \mathrm{L})$ & $\left.\mathbf{( h}^{-\mathbf{1}}\right)$ & $\mathbf{( g / g )}$ & $(\mathrm{g} / \mathrm{L} / \mathbf{h})$ & $(\mathrm{g} / \mathrm{L} / \mathbf{h})$ & $(\%)$ \\
\hline Glucose & $11.13^{\mathrm{a}}$ & $0.12^{\mathrm{a}}$ & $0.55^{\mathrm{a}}$ & $0.46^{\mathrm{a}}$ & $0.76^{\mathrm{a}}$ & $99.61^{\mathrm{a}}$ \\
Dextrin & $4.52^{\mathrm{c}}$ & $0.07^{\mathrm{b}}$ & $0.22^{\mathrm{c}}$ & $0.19^{\mathrm{c}}$ & $0.66^{\mathrm{b}}$ & $39.84^{\mathrm{c}}$ \\
Dextrin with glucoamylase & $9.51^{\mathrm{b}}$ & $0.11^{\mathrm{a}}$ & $0.47^{\mathrm{b}}$ & $0.40^{\mathrm{b}}$ & $0.74^{\mathrm{a}}$ & $85.12^{\mathrm{b}}$ \\
\hline
\end{tabular}

Statistic comparisons of those mean values within their own columns (among carbon sources) at $p$-values of $\leq 0.05$ show different characters, a, b, and c, which indicate statistically significant differences.

The enzyme's optimum temperature and $\mathrm{pH}$ of our own study were at $65^{\circ} \mathrm{C}$ and 4.5 , respectively giving a maximum activity, $\mathrm{u}_{\max }$ at a rate of $0.0073 \mathrm{~g} / \mathrm{g} / \mathrm{L} / \mathrm{min}$ [16]. However, the external glucoamylase supplemented was also active in the same conditions of cell cultivation at a temperature of $30{ }^{\circ} \mathrm{C}$ and a $\mathrm{pH}$ of 4.5 , respectively. (In this in vitro condition, the $\mathrm{u}_{\max }$ was at a rate of $0.0037 \mathrm{~g} / \mathrm{g} / \mathrm{L} / \mathrm{min}$ ). The glucoamylase gradually degraded at the ends of dextrin chains to slowly release glucose monomers for gradual assimilation and consumption by the yeast. So, we suggest that the dextrin oligomer from cassava starch liquefaction here is a very effective potential C-source for S. cerevisiae cultivation when the enzyme is added at an appropriate concentration of $0.1-0.2 \%(v / w)$. Starch hydrolyses, liquefaction and saccharification, in a 10-L stirred tank lysis reactor and their kinetics have been profoundly studied by our group [16]. As dextrin is gradually hydrolyzed by the addition of glucoamylase, a continual gradual release of free glucose molecules occurs at an appropriate rate. Thus, the glucose molecules are proportionally assimilated into the yeast cells without accumulation, congestion, and inhibition.

\subsection{The Use of High Concentrations of Dextrin for S. cerevisiae Cultivation in the 5-L Bioreactors}

To produce experimental results approaching practicable scalability, the larger scale cell cultivations using 5-L bioreactors with fully controlled conditions were carefully undertaken. The optimum concentration of $\mathrm{C}$-sources is very important to enhance cell growth and product formation. The lower the concentration of $\mathrm{C}$-source affects the lower the cell biomass and productivity. When there is an increase in a maximum C-source concentration with appropriate conditions, i.e., sufficient nutrients, dissolved $\mathrm{O}_{2}$, and mixing intensity, etc., the yield and productivity could be proportionally increased and maximized. The excessive C-sources especially for glucose and sucrose affect cell metabolisms and inhibit cell growth and consequential product formation. However, with our strategies here, the cell cultivations with very high concentrations of $C$-source can be achieved although using just the aerobic batch mode.

The experimental results showed that the effective maximum concentration of dextrin used by S. cerevisiae for aerobic batch cultivation without substrate repression problem inhibiting cell growth was at $90 \mathrm{~g} / \mathrm{L}$ in $3 \times$ BPM with $0.9 \%(w / v)$ of YE. It produced the maximum cell biomass within $30 \mathrm{~h}$. A dry cell weight, $x$ at $53.63 \mathrm{~g} / \mathrm{L}$, a specific growth rate, $\mu$ at $0.18 \mathrm{~h}^{-1}$, a cell yield coefficient, $Y_{x / s}$ of $0.54 \mathrm{~g} / \mathrm{g}$, a rate of cell biomass production, $r_{x}$ at $1.79 \mathrm{~g} / \mathrm{L} / \mathrm{h}$, and a rate of substrate utilization, $r_{s}$ at $3.16 \mathrm{~g} / \mathrm{L} / \mathrm{h}$ with $99.00 \%$ efficiency were obtained (Table 4 and Figure 4 ). Clearly, when compared to those of other concentrations, this treatment shows efficient growth performances in terms of: (i) cell biomass growth profile and concentration. (ii) efficient use of C-source dextrin with the optimum concentration, and (iii) rates of biomass production and substrate utilization. 
Table 4. Growth kinetic parameters of S. cerevisiae cultivations in 5-L bioreactors using BPM with dextrin at different concentrations and operating at the impeller speeds of 500,600, 700, and $800 \mathrm{rpm}$, (equivalent to $\bar{\varepsilon}_{T}=1,2,3$, and $4 \mathrm{~W} / \mathrm{kg}$ ) with the airflow rates at 1,2,3, and $4 \mathrm{vvm}$ where they were proportional to the concentrations of dextrin.

\begin{tabular}{ccccccc}
\hline \multirow{2}{*}{$\begin{array}{c}\text { BPM Conc. with } \\
\text { (Dextrin Conc.) }\end{array}$} & $x$ & $\mu$ & $Y_{x / s}$ & $r_{x}$ & $r_{s}$ & Efficiency \\
\cline { 2 - 7 } & $(\mathrm{g} / \mathrm{L})$ & $\left(\mathbf{h}^{-\mathbf{1}}\right)$ & $\mathbf{( g / g )}$ & $(\mathrm{g} / \mathrm{L} / \mathbf{h})$ & $(\mathrm{g} / \mathrm{L} / \mathbf{h})$ & $(\%)$ \\
\hline $1 \times(30 \mathrm{~g} / \mathrm{L})$ & $11.17^{\mathrm{d}}$ & $0.15^{\mathrm{bc}}$ & $0.35^{\mathrm{b}}$ & $0.38^{\mathrm{d}}$ & $0.97^{\mathrm{d}}$ & $64.17^{\mathrm{b}}$ \\
$2 \times(60 \mathrm{~g} / \mathrm{L})$ & $23.60^{\mathrm{c}}$ & $0.16^{\mathrm{b}}$ & $0.36^{\mathrm{b}}$ & $0.98^{\mathrm{c}}$ & $2.07^{\mathrm{c}}$ & $66.00^{\mathrm{b}}$ \\
$3 \times(90 \mathrm{~g} / \mathrm{L})$ & $53.63^{\mathrm{a}}$ & $0.18^{\mathrm{a}}$ & $0.54^{\mathrm{a}}$ & $1.79^{\mathrm{a}}$ & $3.16^{\mathrm{a}}$ & $99.00^{\mathrm{a}}$ \\
$4 \times(120 \mathrm{~g} / \mathrm{L})$ & $42.40^{\mathrm{b}}$ & $0.13^{\mathrm{c}}$ & $0.32^{\mathrm{c}}$ & $1.41^{\mathrm{b}}$ & $2.95^{\mathrm{b}}$ & $57.70^{\mathrm{c}}$ \\
\hline
\end{tabular}

Statistic comparisons of those mean values within their own columns (among dextrin concentrations) at $p$-values of $\leq 0.05$ show different characters, $a, b, c$, and d, which indicate statistically significant differences.
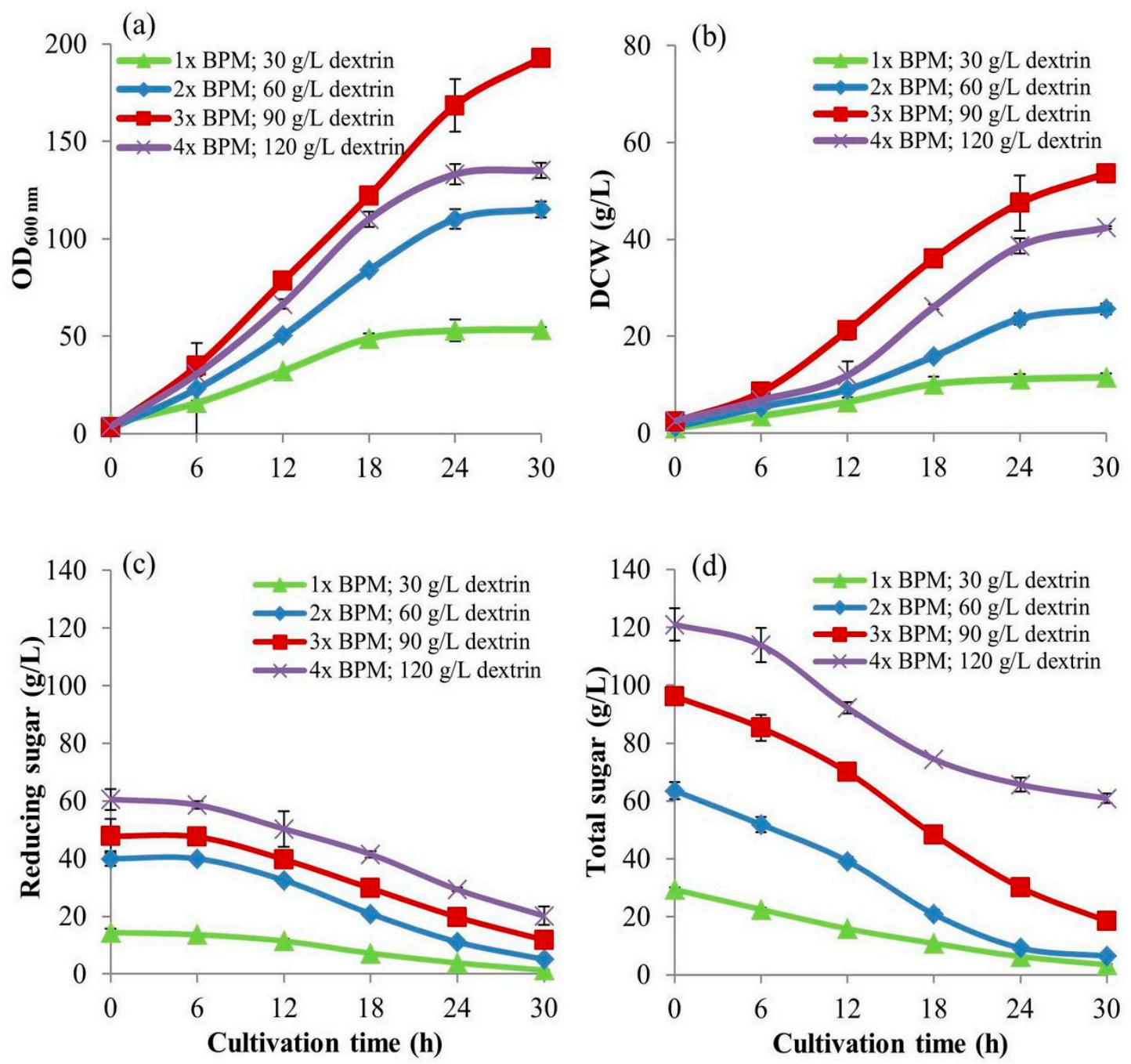

Figure 4. Growth (a) $\mathrm{OD}_{600 \mathrm{~nm}}$ and (b) dry cell weight; substrate utilizations (c) reducing sugar (residual glucose) and (d) total sugar, during cultivations of $S$. cerevisiae in 5-L bioreactors using BPM medium with dextrin at different concentrations of $30,60,90$, and $120 \mathrm{~g} / \mathrm{L}$, and operating at the impeller speeds of 500,600,700, and $800 \mathrm{rpm}$, (equivalent to $\bar{\varepsilon}_{T}=1,2,3$, and $4 \mathrm{~W} / \mathrm{kg}$ ) with the airflow rates at 1, 2, 3, and $4 \mathrm{vvm}$ where they were proportional to the concentrations of dextrin, respectively.

As dextrin is a longer molecule, S. cerevisiae cannot immediately import it into the cells for consumption with the normal pathway, but its need is to be shortened to release glucose and maltose molecules. However, S. cerevisiae cannot do by itself, so external glucoamylase added at an appropriate 
concentration will act as gradually cutting at the ends of their chains and releasing free glucose molecules. Therefore, the amount of glucose released into the culture does not exceed the concentration of using glucose as a direct $C$-source. There is an explanation that glucoamylase is an exoamylase which cleaves 1,4- $\alpha$-glycosidic bonds from the non-reducing ends of the glycosidic chains releasing D-glucose, thus increases the content of fermentable carbohydrates and reduces the non-fermentable dextrin [31]. Yeasts will gradually import glucose and maltose molecules into their cells in the right amount without accumulation until inhibiting the cell growth.

This "dextrin culture" is similar to an SSF (simultaneous scarification and fermentation) for ethanol production from maltodextrin by yeast, but it is not exactly the same herein because aerobic cell cultivation with "starch pre-product" called dextrin at a high concentration has a more difficulty in sufficient-dissolved $\mathrm{O}_{2}$ supply. This problem is overcome by gradually cleaving the dextrin chains to release free glucose molecules gradually instead of the direct use of bulk glucose. As a consequence, they are gradually assimilated into yeast cells without accumulation and congestion to inhibit cell growth. This is a novel technique called "fed-batch at cell level" or FBC. It enhances the utilization of a high concentration of C-source oligomer to boost the production of a high cell biomass. As it is an oligomer, although the aerobic batch cultivation, it can be used at a concentration of $\geq 3-4$ times higher than that of glucose and sucrose. Thus, it is superior to the conventional fed-batch cultivation techniques (Table 5) of which glucose and sucrose at high concentrations must be fed using fed-batch strategies with much longer time courses and complexities.

Table 5. Results of dry cell weight, production rate, and yield coefficient from S. cerevisiae cultivations using fed-batch techniques with different $\mathrm{C}$-sources and cultivation time courses to compare with the result of our research work here.

\begin{tabular}{cccccccc}
\hline $\begin{array}{c}\text { Cultivation } \\
\text { Techniques }\end{array}$ & Carbon Sources & $\begin{array}{c}\text { Substrates } \\
\text { Conc. (g/L) }\end{array}$ & $\begin{array}{c}\text { Cultivation } \\
\text { Time }(\mathbf{h})\end{array}$ & $\begin{array}{c}\text { DCW } \\
(\mathrm{g} / \mathbf{L})\end{array}$ & $\begin{array}{c}\text { Productivity } \\
(\mathrm{g} / \mathrm{L} / \mathbf{h})\end{array}$ & $\boldsymbol{Y}_{x / \mathrm{s}}(\mathrm{g} / \mathrm{g})$ & Ref. \\
\hline Fed-batch & $\begin{array}{c}\text { Molasses and corn } \\
\text { steep liquor }\end{array}$ & $\begin{array}{c}\text { Sucrose (85) } \\
\text { Protein (225) }\end{array}$ & 110 & $187.63 \mathrm{~Np}$ & 1.71 & 0.60 & {$[10]$} \\
\hline Fed-batch & Glucose & Glucose (230) & 65 & 120.00 & 1.84 & 0.52 & {$[11]$} \\
\hline Fed-batch & Molasses & Sucrose (250) & 80 & 95.70 & 1.32 & 0.38 & {$[12]$} \\
\hline Fed-batch & Glucose & $\begin{array}{c}\text { Glucose (200) } \\
\text { YE (15) }\end{array}$ & 50 & $63.3-96.10$ & $1.30-1.99$ & $0.4-0.48$ & {$[13]$} \\
\hline Batch & Dextrin & $\begin{array}{c}\text { Dextrin (90) } \\
\text { YE (9) }\end{array}$ & $\mathbf{2 4}$ & $\mathbf{5 3 . 7 2}$ & $\mathbf{2 . 2 4}$ & $\mathbf{0 . 5 5}$ & This study \\
\hline Np: not practical because of too high a titer of protein used beyond the industrial scalability and profitability.
\end{tabular}

\subsection{The Intensive Multiple Sequential Batch Technique to Achieve High cell density Concentration Superior to the Fed-Batch Technique}

"Intensive" means the use of very high concentrations of C-source together with proportionally high intensities of operations, i.e., agitation speed and airflow rate. HCDC is mainly based on the fed-batch technique with the development of different nutrient feeding strategies, e.g., pH-stat, chemo-stat, exponential feed, etc. They are complicated and use a lot of equipment, time, and investment cost at every scale [32]. Batch cultivation is not popular to implement for high cell density cultivation due to a limitation of using high level of $C$-source which could inhibit cell growth. However, our study recognizes the advantages of batch cultivation, i.e., ease of operation, and preparation of equipment and medium. We have developed the special batch cultivation strategies to compete with the convention fed-batch technique to produce yeast cell biomass at high density concentrations. By finding the effective C-source, formulating a potential minimal medium, operating intense agitation and airflow, and together with the repeating batches without preparations of new equipment, the experiments were done successfully by the so-called "intensive multiple sequential batch" technique. This implementation enables yeast cells to grow continuously at a high rate. It as well as helps reduce difficulties, time, cost, and labor, especially when implemented in the industrial processes. 
In this experiment, the initial batch cultivation was operated with the same optimum conditions as in Section 3.4 above. The $3 \times$ BPM with $90 \mathrm{~g} / \mathrm{L}$ dextrin and $0.9 \%(w / v)$ of YE was used. The optimum conditions, i.e., at $\mathrm{pH}$ of 4.5 , temperature of $30{ }^{\circ} \mathrm{C}$, impeller speed of $700 \mathrm{rpm}$, and aeration rate of $3 \mathrm{vvm}$ were controlled through $24 \mathrm{~h}$ of cultivation. The next four consecutive batches with the same operations were repeated. Table 6 and Figure 5 show the results of $S$. cerevisiae cultivations with intensive multiple sequential batch technique of five-cycle batch runs for a total time course of $120 \mathrm{~h}$. The biomass concentrations at $24 \mathrm{~h}$ in each batch from 1 to 5 were 53.13, 55.17, 53.03, 53.77, and $53.50 \mathrm{~g} / \mathrm{L}$, respectively with an average value at $53.72 \mathrm{~g} / \mathrm{L}$. From all the five sequential batches, the average values, i.e., a specific growth rate, $\mu$ at $0.16 \mathrm{~h}^{-1}$, a yield coefficient, $Y_{x / \mathrm{s}}$ of $0.50 \mathrm{~g} / \mathrm{g}$, a cell productivity, $r_{x}$ at $2.24 \mathrm{~g} / \mathrm{L} / \mathrm{h}$, and a substrate utilization rate, $r_{s}$ at $4.05 \mathrm{~g} / \mathrm{L} / \mathrm{h}(80.93 \mathrm{mmol} / \mathrm{L} / \mathrm{s})$, with an overall efficiency of $90.55 \%$ were obtained. These values are higher than some of those results from the fed-batch cultures in the literature (Table 5).
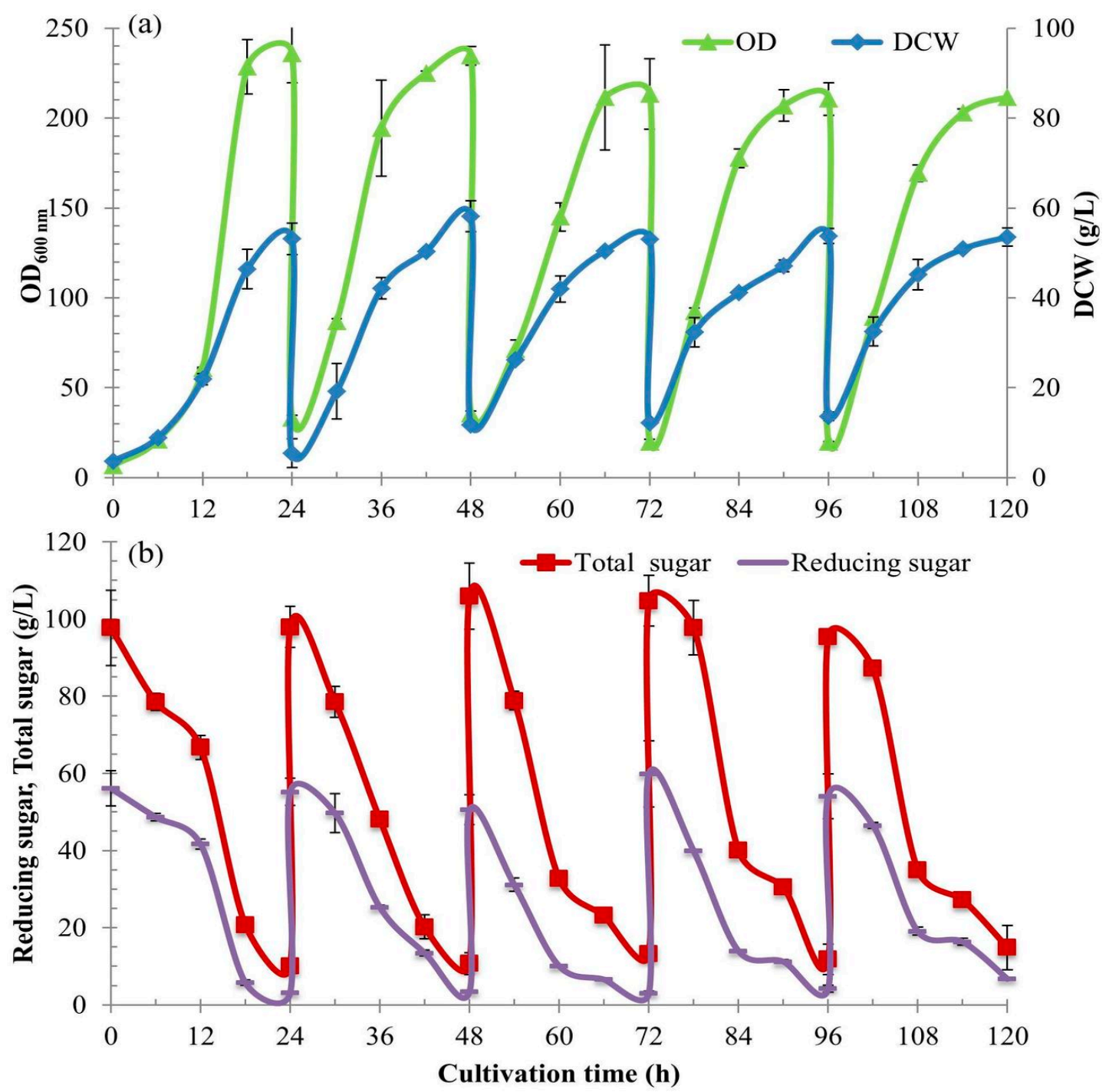

Figure 5. Growth (a) $\mathrm{OD}_{600 \mathrm{~nm}}$ and dry cell weight; (b) substrate utilizations, reducing sugar (residual glucose), $\mathrm{G}_{\mathrm{l}}$ and total sugar, $\mathrm{S}_{\mathrm{T}}$ during cultivations of $\mathrm{S}$. cerevisiae with the intensive multiple sequential batches for 5-cycle runs using $3 \times$ BPM with $90 \mathrm{~g} / \mathrm{L}$ of dextrin and $9 \mathrm{~g} / \mathrm{L}(0.9 \% w / v)$ of yeast extract, operating at the impeller speed of $700 \mathrm{rpm}\left(\bar{\varepsilon}_{T}=3 \mathrm{~W} / \mathrm{kg}\right)$ with the airflow rate at $3 \mathrm{vvm}$. 
Table 6. Growth kinetic parameters of $S$. cerevisiae cultivations with the intensive multiple sequential batches for 5-cycle runs using $3 \times$ BPM with $90 \mathrm{~g} / \mathrm{L}$ of dextrin and $9 \mathrm{~g} / \mathrm{L}(0.9 \% \mathrm{w} / \mathrm{v})$ of yeast extract operating at the impeller speed of $700 \mathrm{rpm}\left(\bar{\varepsilon}_{T}=3 \mathrm{~W} / \mathrm{kg}\right)$ with the airflow rate at $3 \mathrm{vvm}$.

\begin{tabular}{|c|c|c|c|c|c|c|}
\hline \multirow{2}{*}{$\begin{array}{c}\text { (Intensive } \\
\text { Sequential Batches) }\end{array}$} & $x$ & $\mu$ & $Y_{x / s}$ & $r_{x}$ & $r_{s}$ & Efficiency \\
\hline & $(g / L)$ & $\left(h^{-1}\right)$ & $(g / g)$ & $(g / L / h)$ & (g/L/h) & $(\%)$ \\
\hline Batch I & $53.13^{b}$ & $0.15^{b}$ & $0.55^{a}$ & $2.21^{b}$ & $4.02^{b}$ & $100.00^{a}$ \\
\hline Batch II & $55.17^{\mathrm{a}}$ & $0.21^{\mathrm{a}}$ & $0.54^{\mathrm{a}}$ & $2.30^{a}$ & $4.01^{b}$ & $98.18^{a}$ \\
\hline Batch III & $53.03^{b}$ & $0.13^{b}$ & $0.45^{c}$ & $2.21^{b}$ & $4.23^{a}$ & $81.82^{c}$ \\
\hline Batch IV & $53.77^{\mathrm{b}}$ & $0.16^{\mathrm{b}}$ & $0.45^{\mathrm{c}}$ & $2.24^{b}$ & $4.25^{\mathrm{a}}$ & $81.82^{c}$ \\
\hline Batch V & $53.50^{b}$ & $0.14^{\mathrm{b}}$ & $0.50^{b}$ & $2.23^{b}$ & $3.73^{c}$ & $90.91^{b}$ \\
\hline Mean & 53.72 & 0.16 & 0.50 & 2.24 & 4.05 & 90.55 \\
\hline
\end{tabular}

Statistic comparisons of those mean values within their own columns (among sequential batch runs) at $p$-values of $\leq 0.05$ show different characters, $a, b$, and c, which indicate statistically significant differences.

These values are comparable with those of the other high cell density cultivations using the fed-batch strategies. A high cell density cultivation of $S$. cerevisiae using a fed-batch technique was done with feeding the mixture of molasses: corn steep liquor in a ratio of $80: 20 \%(w / v)$. They obtained the maximum cell biomass at $187.63 \mathrm{~g} / \mathrm{L}$ over $110 \mathrm{~h}$ with a productivity of $1.71 \mathrm{~g} / \mathrm{L} / \mathrm{h}$ [10]. A high cell density cultivation with the direct feedback control of glucose using an online ethanol concentration monitor in fed-batch cultivation technique for ergosterol production by $S$. cerevisiae was conducted and obtained a yeast dry weight at $120 \mathrm{~g} / \mathrm{L}$ and the ergosterol yield reached $1500 \mathrm{mg} / \mathrm{L}$ within $65 \mathrm{~h}$ with a cell productivity of $1.84 \mathrm{~g} / \mathrm{L} / \mathrm{h}$ [11]. The cultivations of $S$. cerevisiae were used to produce $\beta$-glucan from molasses and corn steep liquor with batch and fed-batch techniques. A cell biomass in batch culture was at 36.5-39.3 g/L while the maximum biomass in fed-batch culture was at $95.7 \mathrm{~g} / \mathrm{L}$ within $80 \mathrm{~h}$ (2.4-folds higher) with a low productivity of $1.20 \mathrm{~g} / \mathrm{L} / \mathrm{h} \mathrm{[12].} \mathrm{The} \mathrm{yeast} \mathrm{cell} \mathrm{productivity} \mathrm{of} \mathrm{our}$ work here is $2.24 \mathrm{~g} / \mathrm{L} / \mathrm{h}$, which is higher than those of the other research works although they used the fed-batch strategies.

Furthermore, it has been repeatedly stated that the so-called "fed-batch at cell level-FBC" technique is superior to the conventional fed-batch cultivation strategy. However, this statement might have not been sufficiently proved in this study. When a comparison of experimental data on process performance (i.e., biomass productivity, yield coefficient, and concentration), operating under the FBC technique (this study) and the fed-batch cultivation strategies (literature data in Table 5) was attempted, it was shown that the FBC technique prevails over the fed-batch strategies in terms of productivity (due to the faster cultivation), resulting a notably lower dry cell concentration (Table 5). However, when they are considered, i.e., $(53.7 \mathrm{~g} / \mathrm{L}$ vs. $187.6 \mathrm{~g} / \mathrm{L}, 120 \mathrm{~g} / \mathrm{L}$, or $95.7 \mathrm{~g} / \mathrm{L})$, it is correct, but not true. So, they are not comparable; i.e., $53.7 \mathrm{~g} / \mathrm{L} / 24 \mathrm{~h}$ vs. $187.6 \mathrm{~g} / \mathrm{L} / 110 \mathrm{~h}, 120 \mathrm{~g} / \mathrm{L} / 65 \mathrm{~h}$, or $95.7 \mathrm{~g} / \mathrm{L} / 80 \mathrm{~h}$. This is correct and true. So, they are comparable. In fact, the FBC technique is superior to the conventional fed-batch cultivation in terms of (i) less operation complexities, a number of equipment, cost, time, contamination risk, etc. (ii) production mass at a specific time course. For example, if a 20,000-L working volume of cell culture is produced in an industrial bioreactor at a rate of $95.70 \mathrm{~g} / \mathrm{L} / 80 \mathrm{~h}$, a cell biomass of $1914 \mathrm{~kg}$ will be obtained. For the FBC, if a 20,000-L working volume of cell culture is produced using the same industrial bioreactor at a rate of $53.72 \mathrm{~g} / \mathrm{L} / 24 \mathrm{~h}$, a cell biomass of $1074 \mathrm{~kg}$ will be obtained. By using the same time course of $80 \mathrm{~h}$ for operation and the FBC is run with the intensive multiple sequential batch technique, the number of batch cycle is $80 / 24=3.33$. Thus, a cell biomass of $3576.42 \mathrm{~kg}$ will be obtained. That is the reason why the FBC of a high productivity must be operated together with the multiple sequential batch technique. Actually, the FBC can be operated at up to $\geq 7$ cycles (data not shown). Moreover, we have successfully cultivated certain bacteria, i.e., E. coli and Bacillus megatherium, implementing the $\mathrm{FBC}$ technique, and much higher productivities at 3.50 and $3.92 \mathrm{~g} / \mathrm{L} / \mathrm{h}$, respectively have been achieved (results not shown here). 
However, if we think that the lower the culture density, the more reduced the separation efficiency and the greater the required energy, and in the case of industrial bioreactors the processed culture volume is of the order of several thousands of liters or cubic meters, then the advantages of this IMSB technique should be carefully studied. In the industry, all the issues, such as selected technologies, types and sizes of unit operations, investment cost, labor, time, etc. must be considered. They have to be compromised to meet the desired economic values.

\subsection{Sugar Components' Analysis during High Cell Density Cultivation and the Proof of "Fed-Batch at Cell Level" (FBC)}

\subsubsection{Biochemical Engineering Mass Balances}

The overall mass balance equation,

$$
C_{i}=G_{u}+S_{T}
$$

where

$$
S_{T}=D x+G_{l}
$$

Thus, the component mass balances,

$$
G_{u}=C_{i}-S_{T}
$$

and when substitute (2) in (3) then,

$$
G_{u}=C_{i}-\left(D x+G_{l}\right)
$$

So, the dextrin concentration, $D x$ is

$$
D x=C_{i}-\left(G_{u}+G_{l}\right)
$$

where $C_{i}$ is the initial carbon source (dextrin from cassava starch liquefaction), $S_{T}$ is the total sugar left in the system during cell cultivation, $G_{u}$ is the overall glucose which has been taken up into the cells, thus $D x$ and $G_{l}$ are the dextrin left and glucose residue in the system, respectively.

For the overall rates' balances:

From Table 7, the overall rates' balance is

$$
\frac{d G_{l}}{d t}+\frac{d D x}{d t}=\frac{d G_{u}}{d t}=\frac{d S_{T}}{d t}
$$

thus,

$$
r G_{l}+r D x=r G_{u}=r S_{T}
$$

where each " $r$ " represents the rates of each component by which each rate is calculated from the changes (reductions, i.e., $G_{l}, D x, S_{T}$, or increase, i.e., $G_{u}$ ) of each component divided by cultivation times.

From cell cultivation experiments and analyses, as we know (i) $C_{i}$, the initial concentration of C-source used, e.g., $90 \mathrm{~g} / \mathrm{L}$, (ii) $S_{T}$, the total sugar concentration analyzed by complete acid hydrolysis and (iii) $G_{l}$ the glucose left in the system as the reducing sugar by DNS assay. Thus, all those equations can be balanced and found the unknown values of $G_{u}$ and $D x$ (Table 7 and Figures 5-7). This essentially proves that there is continually gradual hydrolysis of dextrin oligomer to release free glucose which is, at the same time, gradually assimilated into the cells proportionally. This importantly supports cell growth with the technique, "fed-batch at cell level" (FBC). Moreover, from Table 7 and Equations (6) and (7), an overall rates' balance equation can be derived as $r G_{l}+r D x=r G_{u}=r S_{T}$, where $r G_{l}$ is the rate of residual glucose utilization and $r D x$ is the rate of dextrin degradation to release free glucose, by which both of them are the sum of total glucose assimilation rate of $r G_{u}$. Both terms of $r G_{l}+r D x$ and $r G_{u}$ are the same rate of the total sugar utilization, $r S_{T}$. As there is an amount of residual glucose in the 
system, it is assimilated into the cells at a rate of almost proportional to the rate of dextrin hydrolysis, $r G_{l}: r D x$, in a ratio of $1: 0.72 \mathrm{~g} / \mathrm{g} / \mathrm{L} / \mathrm{h}$ to a sum of the total glucose assimilation rate. Besides the technique of gradual hydrolysis of dextrin, it is a compromised utilization of glucose from both sources efficiently to prevent the yeast cell system from glucose accumulation and subsequent congestion to cause the Crabtree effect inhibiting cell growth. Again, this phenomenon importantly proves the mechanism of "fed-batch at cell level". Essentially, dextrin plays key roles both in the regulation of the FBC and in the reserved C-source.

Table 7. Concentrations and utilization rates of total sugars, glucose uptake, residual glucose, and dextrin during cultivations of $S$. cerevisiae with the intensive multiple sequential batches for 5-cycle runs using $3 \times \mathrm{BPM}$ with $90 \mathrm{~g} / \mathrm{L}$ of dextrin and $9 \mathrm{~g} / \mathrm{L}(0.9 \% w / v)$ of yeast extract, operating at the impeller speed of $700 \mathrm{rpm}\left(\bar{\varepsilon}_{T}=3 \mathrm{~W} / \mathrm{kg}\right)$ with the airflow rate at $3 \mathrm{vvm}$. This is to show the rates of each sugar component and that of dextrin, the overall rates and its balance equation is to prove the "fed-batch at cell level" (FBC) phenomenon.

\begin{tabular}{|c|c|c|c|c|c|c|c|}
\hline $\begin{array}{l}\text { Continual } \\
\text { Sequential } \\
\text { Batch Runs }\end{array}$ & $\begin{array}{c}\text { Time (h) Each } \\
\text { Batch }\end{array}$ & $\begin{array}{c}\text { Time (h) } \\
\text { Accumulative }\end{array}$ & $\begin{array}{c}\text { Initial } \\
\text { C-Source } \\
C_{i}(\mathrm{~g} / \mathrm{L}) \\
\end{array}$ & $\begin{array}{c}\text { Total } \\
\text { Sugar } \\
S_{T}(\mathrm{~g} / \mathrm{L})\end{array}$ & $\begin{array}{l}\text { Glucose } \\
\text { Uptake } \\
G_{u}(\mathrm{~g} / \mathrm{L})\end{array}$ & $\begin{array}{c}\text { Glucose } \\
\text { Residue } \\
G_{l}(\mathrm{~g} / \mathrm{L})\end{array}$ & $\begin{array}{c}\text { Dextrin } \\
\text { Degraded } \\
D x(g / L)\end{array}$ \\
\hline \multirow{6}{*}{ I } & 0 & 0 & \multirow[t]{5}{*}{97.71} & 97.71 & 0.00 & 56.13 & 41.59 \\
\hline & 6 & 6 & & 78.51 & 19.20 & 48.65 & 29.90 \\
\hline & 12 & 12 & & 66.73 & 31.00 & 41.68 & 25.00 \\
\hline & 18 & 18 & & 20.72 & 77.00 & 5.72 & 15.05 \\
\hline & 24 & 24 & & 10.12 & 87.60 & 3.08 & 7.00 \\
\hline & Rate $(\mathrm{g} / \mathrm{L} / \mathrm{h})$ & & & $3.65^{b}$ & $3.65^{b}$ & $2.21^{\mathrm{b}}$ & $1.44^{\mathrm{c}}$ \\
\hline \multirow{6}{*}{ II } & 0 & 24 & \multirow[t]{5}{*}{98.71} & 97.91 & 0.00 & 55.20 & 42.70 \\
\hline & 6 & 30 & & 78.49 & 19.20 & 49.71 & 29.00 \\
\hline & 12 & 36 & & 48.10 & 49.60 & 25.31 & 23.00 \\
\hline & 18 & 42 & & 20.21 & 77.50 & 13.45 & 7.00 \\
\hline & 24 & 48 & & 10.69 & 87.00 & 3.46 & 7.40 \\
\hline & Rate $(\mathrm{g} / \mathrm{L} / \mathrm{h})$ & & & $3.63^{b}$ & $3.63^{b}$ & $2.16^{b}$ & $1.47^{\mathrm{c}}$ \\
\hline \multirow{6}{*}{ III } & 0 & 48 & \multirow[t]{5}{*}{105.94} & 105.94 & 0.00 & 50.59 & 55.40 \\
\hline & 6 & 54 & & 78.87 & 27.10 & 31.12 & 47.70 \\
\hline & 12 & 60 & & 32.73 & 73.20 & 10.06 & 22.70 \\
\hline & 18 & 66 & & 23.15 & 82.80 & 6.58 & 16.60 \\
\hline & 24 & 72 & & 13.30 & 92.60 & 3.03 & 10.30 \\
\hline & Rate (g/L/h) & & & $3.86^{\mathrm{a}}$ & $3.86^{\mathrm{a}}$ & $1.98^{c}$ & $1.88^{\mathrm{a}}$ \\
\hline \multirow{6}{*}{ IV } & 0 & 72 & \multirow[t]{5}{*}{104.71} & 104.71 & 0.00 & 59.87 & 44.83 \\
\hline & 6 & 78 & & 97.72 & 7.00 & 39.92 & 57.80 \\
\hline & 12 & 84 & & 40.05 & 64.70 & 13.96 & 26.10 \\
\hline & 18 & 90 & & 30.56 & 74.20 & 11.23 & 19.30 \\
\hline & 24 & 96 & & 11.82 & 92.90 & 4.19 & 7.60 \\
\hline & Rate $(\mathrm{g} / \mathrm{L} / \mathrm{h})$ & & & $3.87^{\mathrm{a}}$ & $3.87^{\mathrm{a}}$ & $2.32^{a}$ & $1.55^{b}$ \\
\hline \multirow{8}{*}{ V } & 0 & 96 & \multirow[t]{5}{*}{95.40} & 95.40 & 0.00 & 54.09 & 41.30 \\
\hline & 6 & 102 & & 87.18 & 8.20 & 46.50 & 40.70 \\
\hline & 12 & 108 & & 34.98 & 60.40 & 19.09 & 15.90 \\
\hline & 18 & 114 & & 27.27 & 68.10 & 16.35 & 10.90 \\
\hline & 24 & 120 & & 14.86 & 80.50 & 6.73 & 8.10 \\
\hline & Rate $(\mathrm{g} / \mathrm{L} / \mathrm{h})$ & & & $3.35^{c}$ & $3.35^{c}$ & $1.97^{c}$ & $1.38^{\mathrm{d}}$ \\
\hline & Overall rates & & & $r S_{T}=3.67$ & $r G_{u}=3.67$ & $r G_{l}=2.13$ & $r D x=1.54$ \\
\hline & \multicolumn{3}{|c|}{ Overall rates' balance equation, } & \multicolumn{4}{|c|}{$r S_{T}=r G_{u}=r G_{l}+r D x$} \\
\hline
\end{tabular}

Statistic comparisons of those mean values within their own columns (among sequential batch runs) at $p$-values of $\leq 0.05$ show different characters, a, b, c, and d, which indicate statistically significant differences. 

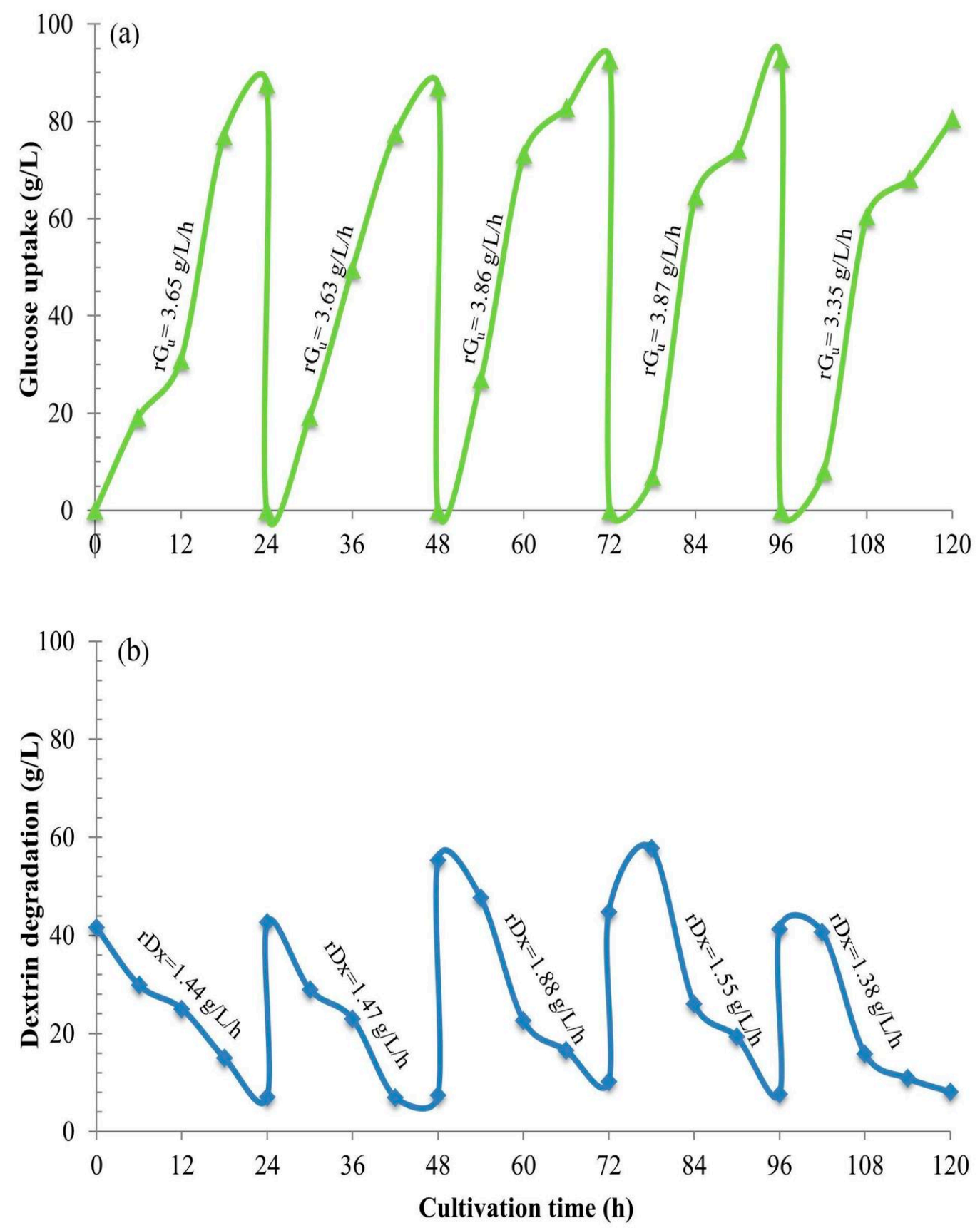

Figure 6. (a) Glucose uptake into the cells (green line) and (b) dextrin hydrolysis to release glucose (blue line), and their rates (slopes of $r G_{u}=d G_{u} / d t$ and $r D x=d D x / d t$ ) during cultivation of $S$. cerevisiae with the intensive multiple sequential batches for 5-cycle runs using $3 \times \mathrm{BPM}$ with $90 \mathrm{~g} / \mathrm{L}$ of dextrin and $9 \mathrm{~g} / \mathrm{L}(0.9 \% w / v)$ of yeast extract, operating at the impeller speed of $700 \mathrm{rpm}\left(\bar{\varepsilon}_{T}=3 \mathrm{~W} / \mathrm{kg}\right)$ with the airflow rate at $3 \mathrm{vvm}$. 


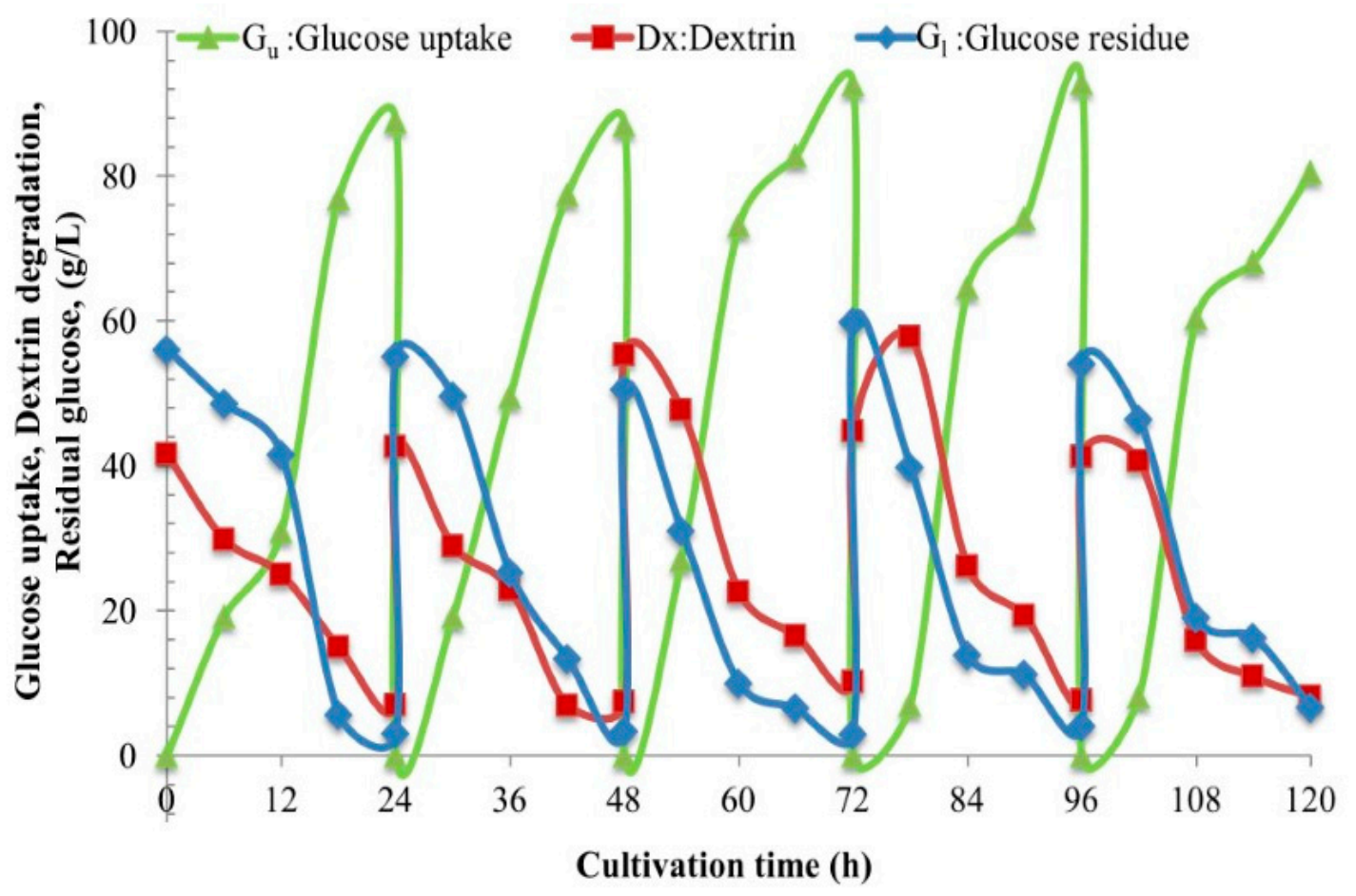

Figure 7. The relationship of the three sugar components during the cultivations of S. cerevisiae with the multiple sequential batches for 5-cycle runs; in each batch, the glucose uptake $\left(G_{u}\right)$ is the sum of dextrin $(D x)$ hydrolyzed to release glucose plus residual glucose $\left(G_{l}\right)$ in the culture system. Thus, $G_{u}=D x+G_{l}$. This obviously shows the "fed-batch at cell level" (FBC) phenomenon. It is the compromised utilization of glucose from both sources during the gradual hydrolysis of dextrin to release glucose.

3.6.2. Proportional Relationship of the Three Sugar Components during the cultivation of S. cerevisiae Controls Fed-Batch at the Cell Level

Figure 7 and Table 7 show a relationship of the three sugar components in the culture system during the cultivation of $S$. cerevisiae with the intensive multiple sequential batches for five-cycle runs. In each batch, the total amount of glucose uptake $\left(G_{u}\right)$ is the sum of dextrin $(D x)$ hydrolyzed to release glucose plus (residual) glucose $\left(G_{l}\right)$. Thus, it is $G_{u}=D x+G_{l}$. Figure 7 is the figurative plot and Table 7 is the constructive numerical approach. They were fabricated to explain this phenomenon in each batch and overall the 5 batches. There are two components of carbon sources, i.e., glucose and dextrin in the culture system in bioreactor. "Glucose is ready to use, but dextrin is to use when ready". Dextrin cannot be utilized directly, but it needs to be hydrolyzed by a supplemented external glucoamylase to release free glucose which is subsequently assimilated into yeast cells. However, glucose from both sources is in the culture system as the mixture, thus it is simultaneously assimilated together into the cells as the glucose uptake $\left(G_{u}\right)$. The concentrations of both glucose and dextrin gradually reduce in a certain proportional ratio. As well as the utilization rates of both C-sources are significantly proportional to a ratio of $1: 0.72 \mathrm{~g} / \mathrm{g} / \mathrm{L} / \mathrm{h}\left(d G_{l} / d t: d D x / d t=2.13: 1.54 \mathrm{~g} / \mathrm{g} / \mathrm{L} / \mathrm{h}\right)$ where the sum is equal to the glucose uptake rate of $d G_{u} / d t=3.67 \mathrm{~g} / \mathrm{L} / \mathrm{h}$. This characteristic evidently shows the compromised use of both carbon sources by yeast cells efficiently in order to prevent the cells from glucose accumulation which will cause the Crabtree effect. In Figure 7, the reduction of glucose line (diamond) means that the major carbon source is utilized by the cells directly while the reduction of dextrin line (square) means that it is gradually hydrolyzed, to reduce the molecular lengths by freeing glucose, and also the reduction of its concentration as it is being utilized. Dextrin plays a key role in being the reserved C-source as it is hydrolyzed when needed. This state-of-the-art technique is very essential to regulate the gradual glucose uptake into the yeast cells at an appropriate rate like "fed-batch at cell level" (FBC). Unlike the control of feed rates of glucose solution into the fermenter in 
conventional fed-batch technique, the FBC here has greater efficiency and many advantages which have been listed in Section 5 .

\subsection{The Proposed Scale-Up Strategies for High Cell Density Production}

The scale-up strategies [19] for the high cell density production from the 5-L laboratory bioreactors to the larger pilot scales and up to the industrial scales are on the basis of fluid dynamic principles in the Section 2.15, where they were used to design the required impeller speeds $(\mathrm{N})$ and given the result in the Table 1, based on the designed variables, called the power input or energy dissipation rate per unit mass, $\bar{\varepsilon}_{T}(\mathrm{~W} / \mathrm{kg})$. At the industrial-scale aerobic cell cultivation using C-source at a concentration of $\sim 30 \mathrm{~g} / \mathrm{L}$, the designed $\bar{\varepsilon}_{T}$ value is $\sim 1$ (W/kg) [19-21]. Thus, if the C-source concentrations are 60, 90 , and $120 \mathrm{~g} / \mathrm{L}$, the desired $\bar{\varepsilon}_{T}$ values are $\sim 2,3$, and $4(\mathrm{~W} / \mathrm{kg})$, respectively. So, if a designed $\bar{\varepsilon}_{T}$ value is fixed, all the geometries, parameters, and the designed operating impeller speed of a larger-scale bioreactor can be calculated using the equation,

$$
\bar{\varepsilon}_{T}=\frac{n P o \rho N^{3} D^{5}}{\rho V}
$$

where $n$ is the number of impellers of 3 for a larger-scale bioreactor, $P o_{g}$ is 2.4 for the power number of Rushton turbine in fluid with air sparging, $\rho$ is $\sim 1050\left(\mathrm{~kg} / \mathrm{m}^{3}\right)$ for culture broth density, $N$ is the impeller speed (rps), and $D$ is the impeller diameter $=1 / 3(\mathrm{~m})$ of the bioreactor diameter, $T(\mathrm{~m}), V$ is the designed volume of the reactor $\left(\mathrm{m}^{3}\right)$ such as $1-200 \mathrm{~m}^{3}$. It is very important to note that the aspect ratio, $\mathrm{H} / \mathrm{T}$ must be between $1-2$, preferably $1-1.5$, where $\mathrm{H}$ is the bioreactor or fluid height in bioreactor $(\mathrm{m})$. Also, for other stirred-tank reactors using this type of impeller without air sparging, the Pog changes to Po with its another value of 5 [19-21]. Also, other types of impellers with and without air sparging can be designed using the same principles.

Furthermore, for the design of the motor power to drive the three Rushton turbine impellers at a range of the designed speeds, the power of the motor, $P(\mathrm{~W})$ is calculated from

$$
P=n P o_{g} \rho N^{3} D^{5}
$$

This bioreactor design and scale-up strategies are very practical and have been used for the design of both pilot-scale bioreactors of 75-L, 200-L, and 750-L volumes and industrial bioreactors of $2000 \mathrm{~L}$ and 100,000 L successfully by the major corresponding author (results not shown here). Thus, it is practicable for the design of bioreactors for the high cell density production of yeast biomass.

\section{Conclusions}

The BPM with $90 \mathrm{~g} / \mathrm{L}$ of dextrin C-source supplemented with YE at $0.9 \%(w / v)$ as a source of nutrients is very effective for the high cell density cultivation of $S$. cerevisiae. This medium enhances excellent cell growth for the production of yeast biomasses and/or their products. As the BPM is very simple and cheap, it is suitable for industrial applications. S. cerevisiae can efficiently use glucose from the gradual hydrolysis of dextrin. Dextrin from cassava starch liquefaction, the major C-source in BPM is more efficient than using commercial pure glucose for the production of yeast cell biomass at high density. It can substitute the major popular C-sources like glucose and/or sucrose which often cause the Crabtree effect inhibiting cell growth. Dextrin can be added into the BPM at a high concentration of $\geq 90 \mathrm{~g} / \mathrm{L}$ for aerobic batch cultivation without the problem of too high a C-source concentration, as it regulates the assimilation of glucose at the cell level (FBC). The single 5-L batch cultivation provided the highest values of cell concentration $(x)$, specific growth rate $(\mu)$, cell yield coefficient $\left(Y_{x / s}\right)$, cell productivity $\left(r_{x}\right)$, and efficiency $(E f)$, at $55.17 \mathrm{~g} / \mathrm{L}, 0.21 \mathrm{~h}^{-1}, 0.54 \mathrm{~g} / \mathrm{g}, 2.30 \mathrm{~g} / \mathrm{L} / \mathrm{h}$, and $98.18 \%$, respectively. To achieve higher yields, the intensive multiple sequential batches (IMSB) cultivation was designed and operated for five sequential batch runs. It showed very good results of those average values at $53.72 \mathrm{~g} / \mathrm{L}, 0.16 \mathrm{~h}^{-1}, 0.50 \mathrm{~g} / \mathrm{g}, 2.24 \mathrm{~g} / \mathrm{L} / \mathrm{h}$, and $90.55 \%$, respectively. With the 
studies of cell growth kinetics, biochemical engineering mass balances, and fluid dynamics in the bioreactors during cultivations, the production of yeast cell biomass at high density using dextrin at high concentrations can be scaled-up to the industries.

\section{The Advantages}

Again, we concluded that the advantages of this research work are as follows: (i) BPM, a minimal defined medium with YE, has a very high potential in terms of cost and efficient use for the production of $S$. cerevisiae biomass at a high density concentration with just an aerobic batch mode rather than using the fed-batch technique with a more complicated operation and longer time course. (ii) Dextrin, an oligomer of glucose from cassava starch liquefaction, is one of the best $C$-sources for aerobic batch cultivation to produce yeast cell biomass at a high concentration other than using the commercial glucose or/and sucrose. (iii) Dextrin can be used at a very high concentration $\geq 100 \mathrm{~g} / \mathrm{L}$ with an aerobic batch mode without the Crabtree effect whereas glucose and sucrose cannot be done. With gradual hydrolysis, it regulates the gradual assimilation of glucose into the yeast cells like "fed-batch at cell level" (FBC), so no glucose accumulation and congestion in the cells will cause $\mathrm{O}_{2}$ deficiency, enhancing the production of toxic by-products, i.e., ethanol in yeasts and acetate in bacteria, to inhibit cell growth. (iv) The intensive multiple sequential batch technique (IMSB) achieves high cell density concentration superior to the fed-batch technique, but it has fewer complications. (v) The kinetics of cell growth, substrate use, and product formation can be utilized to monitor, predict, validate, and control the cultivation to achieve high cell biomass. (vi) As a limitation of HPLC, the biochemical engineering mass balances of our work here are a key model of a very powerful tool implemented to quantify the unknown C-source components, i.e., dextrin and glucose uptake, both in terms of concentration and rate. (vii) Using fluid dynamics in biochemical engineering principles, the stirred-tank bioreactors at every scale can be designed and scaled-up to the industries. (viii) All (v), (vi), and (vii) are very crucial for the production of yeast and other microbial cell biomasses and their products at high concentrations in all scales of operations throughout the industries.

Author Contributions: Conceptualization, K.M. and M.K.; methodology, investigation, analysis, and writing-original draft preparation, J.S.; resources, validation, visualization, and data curation, S.C. and K.R.; writing - review and editing, validation, visualization, supervision, project administration, and funding acquisition. All authors have read and agreed to the published version of the manuscript.

Funding: A research grant, Grant No. 90/2559, was from The National Research Council of Thailand. This work was also supported by the Biochemical Engineering Pilot Plant, Biological Science Graduate Program, and Department of Biology, Faculty of Science, Burapha University, Chon Buri, Thailand.

Acknowledgments: The authors would like to sincerely thank Siripong Premjet, Daungjai Ochaikul, and Patcharanan Amornrattanpan, for their suggestions to the experimental report, and Kanyawe Kukam who supported her ideas, labor, and help in some experiments of this study.

Conflicts of Interest: The authors declare no conflict of interest. The funder had no role in the design of this study, analyses, or interpretation of data; in writing of the manuscript, or the decision to publish the experimental results.

\section{References}

1. Gómez-Pastor, R.; Pérez-Torrado, R.; Garre1, E.; Matallana, E. Recent advances in yeast biomass production. In Biomass-Detection, Production and Usage; InTech: Rijeka, Croatia, 2011; pp. 202-222. [CrossRef]

2. WFMJ. Global Active Dry Yeast Market 2020 Size, Share, Growth, Trends and Forecast 2024, BUSINESS Opportunities and Future Investments; WFMJ Press Release: Youngstown, OH, USA, 2020.

3. Forster, J.; Famili, I.; Fu, P.; Palsson, B.; Nielsen, J. Genome-scale reconstruction of the Saccharomyces cerevisiae metabolic network. Genome Res. 2003, 13, 244-253. [CrossRef] [PubMed]

4. Parapouli, M.; Vasileiadis, A.; Afendra, A.S.; Hatziloukas, E. Saccharomyces cerevisiae and its industrial applications. Aims Microbiol. 2020, 6, 1-31. [PubMed]

5. Peris, D.; Pérez-Torrado, R.; Hittinger, C.T. On the origins and industrial applications of Saccharomyces cerevisiae $\times$ Saccharomyces kudriavzevii hybrids. Yeast 2018, 35, 51-69. [PubMed] 
6. Chen, R.; Yang, S.; Zhang, L.; Zhou, Y.J. Advanced strategies for production of natural products in yeast. Cell Press Rewiews Isc. 2020, 23, 1-23. [CrossRef] [PubMed]

7. Subramaniam, R. High-density cultivation in the production of microbial products. Chem. Biochem. Eng. Q. 2019, 32, 451-464. [CrossRef]

8. Falco, F.; Landi, C.; Paciello, L.; Zueco, J.; Parascandola, P. Fed-batch production of endoglucanase with a recombinant industrial strain of the yeast Saccharomyces cerevisiae. Chem. Eng. Trans. 2014, 38, 379-384.

9. Panda, K.; Khan, R.H.; Mishra, S.; Rao, K.B.C.A.; Totey, S.M. Influences of yeast extract on specific cellular yield of ovine growth hormone during fed-batch fermentation of E. coli. Bioprocess Eng. 2000, 22, 379-383. [CrossRef]

10. Vu, L.; Hanh, V.; Kim, K. High-cell-density fed-batch culture of Saccharomyces cerevisiae kv-25 using molasses and corn steep. J. Microbiol. Biotechnol. 2009, 19, 1603-1611. [CrossRef]

11. Shang, F.; Wen, S.; Wang, X.; Tan, T. High-cell-density fermentation for ergosterol production by Saccharomyces cerevisiae. J. Biosci. Bioeng. 2006, 101, 38-41. [CrossRef]

12. Kim, H.Y.; Kang, S.W.; Lee, J.H.; Chang, H.I.; Yum, C.W.; Paik, H.D.; Kang, C.; Kim, S.W. High-cell-density fermentation of Saccharomyces cerevisiae JUL3 in fed-batch culture for the production in bata-glucan. J. Ind. Eng. Chem. 2007, 13, 153-158.

13. Lorenz, E.; Schmacht, M.; Stahl, U.; Senz, M. Enhanced incorporation yield of cysteine for glutathione overproduction by fed-batch fermentation of Saccharomyces cerevisiae. J. Biotechnol. 2015, 216, 131-139. [CrossRef] [PubMed]

14. Xiberras, J.; Klein, M.; Nevoigt, E. Glycerol as a substrate for Saccharomyces cerevisiae based bioprocesses-Knowledge gaps regarding the central carbon catabolism of this "non-fermentable" carbon source. Biotechnol. Adv. 2019, 37, 1-15. [CrossRef] [PubMed]

15. Malairuang, K. High-cell-density cultivation of three model microogranisms with intensively multiple sequential batch technique. Ph.D. Thesis, Faculty of Science, Burapha University, Chon Buri, Thailand, 2019.

16. Sawangwan, C. Starch Hydrolysis in a Stirred-Tank Lysis Reactor. Master of Science Thesis, Burapha University, Chon Buri, Thailand, 2005.

17. Malairuang, K.; Krajang, M.; Rotsattarat, R.; Chamsart, S. Intensive multiple sequential batch simultaneous saccharification and cultivation of Kluyveromyces marxianus SS106 thermotolerant yeast strain for single-step ethanol fermentation from raw cassava starch. Process. Spec. Issue Adv. Microb. Ferment. Process. 2020, 8, 898. [CrossRef]

18. Miller, G.L. Use of dinitrosalicylic acid reagent for determination of reducing sugar. Anal. Chem. 1959, 31, 426-428. [CrossRef]

19. Chamsart, S. A Cell Lysis Reactor for the Production of Plasmid DNA from Recombinant E. coli for Gene Therapy. Ph.D. Thesis, School of Chemical Engineering, The University of Birmingham, Birmingham, UK, 2001.

20. Chamsart, S.; Patel, H.; Hanak, J.A.J.; Hitchcock, A.G.; Nienow, A.W. The impact of fluid-dynamic-generated stresses on chDNA stability during alkaline cell lysis for gene therapy. Biotechnol. Bioeng. 2001, 75, 387-392. [CrossRef] [PubMed]

21. Nienow, A.W. Bioreactor and Bioprocess Fluid Dynamics (British Hydromechanics Research Group (REP)), 1st ed.; Wiley: London, UK, 1997; ISBN 13-978-1860580901.

22. Rouf, A.; Kanojia, V.; Naik, H.R.; Naseer, B.; Qadri, T. An overview of microbial cell culture. J. Pharmacogn. Phytochem. 2017, 6, 1923-1928.

23. Diederichs, S.; Korona, A.; Staaden, A.; Kroutil, W.; Honda, K.; Ohtake, H.; Büchs, J. Phenotyping the quality of complex medium components by simple online-monitored shake flask experiments. Microb. Cell Factories 2014, 13, 149. [CrossRef]

24. Zhang, G.; Mills, D.A.; Block, D.E. Development of chemically defined media supporting high-cell-density growth of Lactococci, Enterococci, and Streptococci. Appl. Environ. Microbiol. 2009, 75, 1080-1087. [CrossRef]

25. Tripathi, N.K.; Sathyaseelan, K.; Jana, A.M.; Rao, P.V.L. High yield production of heterologous proteins with Escherichia coli. Def. Sci. J. 2009, 59, 137-146.

26. Mezule, L.; Delecka, B. Adjustment of yeast growth media for the fermentation of lignocellulosic sugar. Chem. Eng. Trans. 2017, 57, 25-30. 
27. Charoensapharat, K.; Wechgama, K. Effect of initial cells, yeast extract, and sugar concentrations on ethanol production from molasses by thermotolerant yeast Saccharomyces cerevisiae RMU Y-10. Asia Pac. J. Sci. Technol. 2019, 24, 1-6.

28. Raj, E.A.; Kumar, S.H.S.; Kumar, S.U.; Misra, M.C.; Ghildyal, N.P.; Karanth, N.G. High-cell-density fermentation of recombinant Saccharomyces cerevisiae using glycerol. Biotechnol. Prog. 2002, 18, 1130-1132.

29. Turcotte, B.; Liang, X.B.; Robert, F.; Soontorngun, N. Transcriptional regulation of non-fermentable carbon utilization in budding yeast. Fed. Eur. Microbiol. Soc. 2010, 10, 2-13.

30. Daran, L.P.; Jansen, M.L.A.; Daran, J.M.; van Gulik, W.; de Winde, J.H.; Pronk, J.T. Role of transcriptional regulation in controlling fluxes in central carbon metabolism of Saccharomyces cerevisiae: A chemostat culture study. J. Biol. Chem. 2004, 279, 9125-9138. [CrossRef] [PubMed]

31. Trono, D. Recombinant enzymes in the food and pharmaceutical. Ind. Adv. Enzym. Technol. 2019, 20, 349-387.

32. Boos, W.; Shuman, H. Maltose and maltodextrin system of Escherichia coli: Transport, metabolism and regulation. Microbiol. Mol. Biol. Rev. 1998, 62, 204-229. [CrossRef]

Publisher's Note: MDPI stays neutral with regard to jurisdictional claims in published maps and institutional affiliations.

(C) 2020 by the authors. Licensee MDPI, Basel, Switzerland. This article is an open access article distributed under the terms and conditions of the Creative Commons Attribution (CC BY) license (http://creativecommons.org/licenses/by/4.0/). 